\title{
Some Weapons of the Gods in Ancient Egypt until the End of the New Kingdom
}

\author{
Dr. Iman Muhammad Ahmad El-Mahdy \\ Associated Professor at the Faculty of Tourism and Hotels, \\ Tourism Guidance department - University of Sadat City
}

\begin{abstract}
This paper studies the appearance and role of some weapons which associated with the gods in ancient Egypt and shows its aspects and its scenes. The paper concluded that the physical weapons which appeared with the gods were used in the battles and conflicts from ancient times so most of the gods who used these weapons were represented in human form or in animal form with human hands holding the weapons. In addition to the physical weapons there were incorporeal weapons such as the magic. The hands and the wings were used also for protection.
\end{abstract}

Keywords: Weapons, Gods, Ancient Egypt, New Kingdom.

\section{Introduction}

From most ancient times the Weapons were used in Egypt such as the spears, the battleaxe and the maces for the defense of the land as the scenes showed on the most ancient archaeological artifacts such as palettes, knives and maces but the ancient Egyptians sought the power and the support from their gods who supported and accompanied them with their weapons as it was appeared on the top of the lion and enemies palette where the standards of the gods with human hands leads the prisoners. (fig. 1).

The study focuses on the association between some gods and some weapons such as knife, staves, bows, arrows, etc., and searches for this phenomenon in an attempt to understand and explain the motivation for using the weapons by the gods.

To the best of my knowledge the importance of this paper appears because there are not enough studies for weapons of the gods as an integrated subject but there were some sporadic studies such as the study of magical staves (منى 2010م), studies relating to certain kinds of knives and studies relating to fire or weapons in general (Ian Shaw 1991) but these studies remain sporadic. In this paper I will try as much as possible to present integrated study to this subject.

In this study I follow the survey method which is based on a survey (collection) the largest number of texts and representations to extract information relating to weapons of gods and I'll try to find out the relationship between god and the type of weapon which has been associated with him and whether to connect with that the most ancient gods who held the weapons were in human form such as Neith and Andjety. 


\section{Physical Weapons:}

\subsection{Staves and its types:}

\subsubsection{Staves: $\bullet m d w(\mathbf{w b}, \mathbf{I I}, \mathbf{1 7 8})$ :}

The staves were known within the vocabulary and the determinatives of hieroglyphic writing and were mentioned in the dictionaries of ancient Egyptian language, and most notably what Gardiner mentioned (Gardiner

1975, 571-550): $m d w n i 3 w($ Staff of old age) becausethe staff is one of accessories of the old men who lean on it and it was also a symbol of high rank men like the staff in the hand of ka'aper.

The staff had multiple forms which developed with the time from the branches of the trees into the mace. The archaeological evidences, which have been reached us until now, have indicated that the most ancient example of association between the staves and the deities was god Andjety. He was one of the first deities who associated with the staff and represented holding the staff in his hand from early times (Otto 269-270). In early times the bearer of staff was the chief of tribe or the king and in this period the gods also carried the staves (Hassan 1976, 170).

The association between the god Andjety and the staves $m d w$ was mentioned in the pyramid texts:

\section{$m d w . k$ hnti $3 h t$}

(May) your staff be in front of the spirits (control them) (منى 2010، 8 )

Because of the association between the staff and the gods, it was called the holy one $p 3 m d w \breve{s p s i}$. This name was known from the beginning of the $18^{\text {th }}$ dynasty to the Graeco-Roman period(1)، (نى 2010).

The staves associated with the names of some deities such as Seth. The coffin texts mentioned Seth with staff in his hand to subject the public because it was a tool to control and a symbol of power(CT.VI, $172 \mathrm{k}-\mathrm{m})$.

$$
\text { gm.n.f Sth im.s mdw.f } m^{\top} . f \text { hr } d r p^{\ulcorner} t(n) N \text { pn }
$$

Seth found in it (i.e. in the palace) and his staff was in his hand, controlling the public [for] me (Leitz, VII, 122)

God Horus was one of the deities who associated with the staves $m d w H r$. This association was mentioned in Spells 313 and 473 of Coffin Texts(CT.IV 172 m-r, CT.VI 5 b-c, Faulkner 235)

Some Staves, whose end has a falcon head, were found such as the wooden staves which discovered inside the tomb of the king Horwahibre. Its height is about a meter and it carries the gilded facial head of Horus and has marks in blue(De Morgan 96). (fig. 2).

The Staves of Horus were mentioned in the Spell 92 of Book of The Dead.

$$
H r \quad n d \underline{d} h r \text { itf } f \text { inj it.f } m w t . f \quad m \quad m d w . f
$$

"Horus, savior of his father, who brings his father and brings his mother by his staff" (Faulkner 1985, 87). 
This staff was the sacred care staff which had the divine power and may have been the staff with curved end $\rceil$ cwt which was held by Andjety (fig 3).

The Pyramid Texts referred to staves of Anubis (Pyr. $220 \mathrm{~b}-\mathrm{c}$ ) and there were the staves of Osiris which appeared in the upper Register of the $2^{\text {nd }}$ hour of the Book of Amduat as upright staves which has ended with a snake head. These staves were called $m d w n$ wsir (Leitz 465)"Staff of Osiris" in the texts. It associated also with the god Re-Horakhty and was depicted with the head of Re-Horakhty on its top in the scenes of some private tombs such as TT 192 and TT 188. Here the importance of staves was destroying the enemies as the text of the Edfu temple referred (Edfou I, 2, 302, 13). There were also the staves of Amun which appeared in the $18^{\text {th }}$ Dynasty(Van de Walle 1952. 113, Mariette, Deir 1877) and the staves of Khnum which were used to smite the enemies as the text referred.

$$
M d w . f \quad h r \text { tp } n \text { hftiw.f }
$$

"His staff is on the head of his enemies"(Leitz 466)

The holy staff of the god Montu appeared with the statue of the king Ramesses Ilin the Egyptian Museum JE. 44668.

There were also the staves of Apis (Geb) $m d w-G p(\mathrm{~Wb}$. II, 178, 14).

Sometimes these staves were represented in straight form and ended with the head of the deity (fig. 4).

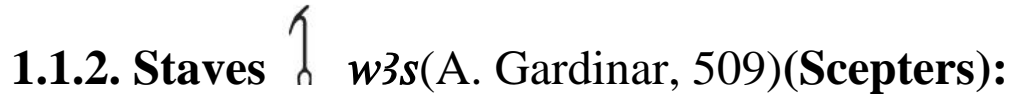

This form of staves appeared from prehistoric times (Martin 1152). It was carved on the ivory comb which was found in Abydos and was dated to $1^{\text {st }}$ dynasty(منى 199 2010، It was mentioned in the Pyramid Texts pyr.866. The w3s Scepter associated with the god Seth who was represented in the form of hybrid animal belonging to the dog family (H. Te Velde 1967, 89-91). Seth had a rectangular face, truncated ears and a tail. The $w 3$ s Scepter staff ended with what was like the head of Seth animal (fig 5).

As a result of the contending of Horus and Seth on the throne and after the agreement of the gods on the rights of Horus to the royal crown, the scepter of Seth became one of royal symbols. Through it the king gains the divine character and becomes the heir of god because this scepter which was carried by the king in his hand was inherited from Osiris to his son.

The w3s Staff (Gordon \& Schwobe 1995, 187) was one of royal insignias and gave the health and the prosperity to its owner (Hayes 284). Its meaning indicates to the power and the authority so it appears in the hands of the deities of the king.

As the gods carried the $w 3 s$ Scepter, the goddesses also carried it such as the goddess Anuket (Anukis)(H. Kees 1941, 25)which had a title "Mistress of southern countries" 'nkt nbt $t$ క šm $i$ and titles "Mistress of Sehel" and "Mistress of Elephantine". She was represented in human form wearing a plumed crown. Anuket appeared on the stela of Amenhotep III standing behind the king in human form wearing long tight dress with braces holding w3s Scepter in her 
left hand while she stretches her right hand to protect the king. The king smites the heads of two enemies crouching before him by his mace and the god Amun standing in front of him(Junker, H., Winter, E., 1965, 158-159).

The god Seth appeared in human form holding the w3s staff and Ankh sign, his head represented as a head of his fabulous animal (Leitz 691). He appeared in the same form on the seals of king Peribsen from the $2^{\text {nd }}$ Dynasty (Hornung, E., 1982, 169). The $w 3 s$ sign appeared before that in the $1^{\text {st }}$ Dynasty on the ivory comb bearing the name of the king Djer.

There was a text on one of papyrus of Middle Kingdom depicting the two testicles of Seth in the form of two scepters. This text narrated a part of the childhood of Horus (Griffith 1898, 4), (أمال 54).

$\underline{d}^{\top} m$ is another name for Seth staff. This staff has the same form of w3s staff but it was corrugated contrary to the straight $w 3 s$ staff. Both staffs ended with a head of Seth animal. It seems that Seth used this weapon in his contendings with Horus as the Chester Beatty Papyrus mentioned (P. Chester Beaty I, 5, 1-5.2).

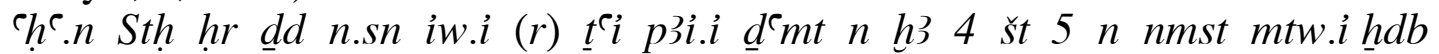
$w$ Cim.tn $m$ mnt $\underline{d}^{\top} m t$

Seth said to the group of gods who ruled in favour of Horus: "I'll take the $\underline{d}^{\top} m t$ staff which belongs to me, (which weighs) 4500 pounds and kill one

of you by it in everyday"(14 2010، (ن)ى)

Seth threatened the Ennead with destroying and killing by this staff. Seth used the weapons because he was a warrior-god. The Pyramid Texts (Allen, pyr. 1145) and the Coffin Texts (De Buck, 167) referred to the power of Seth. One who has a great power was one of the titles of Seth and Seth was "Lord of metals" in particular iron. The iron was known as "bones of Seth" (Wilkinson, 199). The gods used the w3s scepter to give life to the king (fig. 6).

\subsubsection{The Scepter ? $h k 3$ (Gardiner 1973, 583):}

It is a symbol of the ruler, the chief or the king and one of the symbols of authority. It was a bent staff and its origins get back the staff of shepherd( عبد 36 (الحليم (fig. 7). In the beginning, the staff of shepherd was called ' $w t$ (Wb. I, 170, 6)(fig. 8a, 8b) and appeared in the Sed-Festivals (Martin, 821), then it was developed into $h k 3$ staff which was taken by the king from Osiris. Originally it belonged to the god Andjety (Hassan, 1976) so it was always in the hands of the king, the god or in other words, it was held by the great men who had the prestige and authority. It might have been the aim of its bent that it was used to bring stray sheep at the beginning of its use by the shepherds and this staff is still used to lean on it when it is more length.

1.2. Knives $ح d s($ Petie 1917, 109-113), (Wb. V, 486, 7): (fig 9a)

The Knives have been found in Egypt since most ancient times, some knives were found since late predynastic period (Gardiner 1973, 616), (Wolfang 109- 
113) (fig. 9b). Sometimes the use of Knives was practically and sometimes magically by spoken spells to show the impact of the knife as some scenes showed. In these scenes, the knife penetrates the neck of a person and blood drips from it(Posner 1958, 256). The knives connected with some magical spells which were recited to repel the snakes about the person.There was a association between magical amulets and Isis which was often used to repel the enemies whether they were human beings, animals, snakes or harmful insects as stated in the Turin Papyrus(Ritner, 164), (Pleyte, and Rossi, 1869-76,).

The god Bes associated with using what were called the magical knives since the Middle Kingdom. These knives were flat crescent shaped form and were made of lower canines of hippopotamus, wood or ceramics andengraved with some scenes and texts which were considered as a magical weapon to expel evil spirits and protect its owner. Some texts mentioned its role and function such as:

"Cut off the male enemy's head and female enemy's head who enter the chamber of children who were given birth by (so and so)" (عزة فاروق 2006، 4243).

The god Ha $h 3$ associated with the knife. He was one of the gods of desert or foreign countries. He appeared since $3^{\text {rd }}$ Dynasty and sometimes was depicted holding the knife or bow a symbol for his role in the protection (Wilkinson, 106).

The Pyramid Texts (Texts of Unas Pyramid) referred to the god Khonsu as a butcher of the god (والاس بدج، 73):

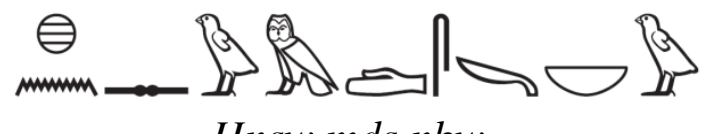

Hnsw mds nbw

The god Thoth associated with the knife in one of his titles (Boylan1987, 181).

The Knives were used in cutting the heads of the guilty ones in the afterlife so the ancient Egyptian made the reserve heads and put them in the tombs (Picardo 2007, 221-252).

Sekhmet was worshipped as a goddess of war and accompanied the king in his campaigns to inspire terror in the hearts of enemies and breathing fire in their faces. Her shape which was in woman form with lioness head showed her strength. She was one of the deities which used the knife so sometimes she was depicted while she was raising her hands, waving with a knife and wearing red tight dress (Lex, V, 323 - 333).

The scenes and the Books of Underworld showed the use of the knife in the afterlife. It was used by gatekeepers who brandished their knives in the afterlife (scene on one of shrines of Tutankhamen, scenes from the Books of Underworld in the valley of kings' tombs such as Thutmosis III's tomb, Amenhotep II tomb, etc.) (fig. 9c).

\subsection{Harpoon and Spear:}


Harpoon is one of the military tools and is different from the spear. It was made of a long piece of wood with a sharp-pointed end. It was also made of metal.

The harpoons were known in Egypt since the most ancient times. It was found a copper blade of harpoon with remains of its handle in el-Mahasna. It جيفري 1999، ) جas dated to late predynastic period and its length was 15.5 cm. 64) (fig 10).

The harpoon appeared in the hands of many deities. Inhert (Anhur) ( أحمد 2008) was one of these deities who carried the title $s m 3$ "the cutter, the sharp one or the one who has strong arm". He was depicted in a human form with a falcon head (because he associated with one of aspects of the god Horus) holding the spear stabbing his enemy. He was one of the gods of war. (he was called Onuris in the Greek period).

Horus Behedety was one of aspects of Horus, avenger of his father on Seth. He fought the enemies of Re in Nubia and appeared holding long spear in his hand stabbing a hippopotamus.

It was also used by the foreign gods in Egypt, such as the Syrian gods: Anat, Astarte and Reshef (Reshep) (Decker 1984, 1124-1125). 'bbt was one of its names (Wb. I, p. 139, 13-15). Anat also used a battleaxe.

The spear was used by Horus Behedety "Horus defeated Seth who was in a hippopotamus form" as the text referred. While Horus of Edfu was also able to save nascent world from the chaos attacks by virtue of his magical spear, Seth had played an important role in the Underworld in virtue of his protection for the bark of the sun-god Re (إيمان 2015) against the threats of Apophis by using his spear representing the strength of brute sun $(\mathrm{H}$. Te Velde, 89-91).

According to the myth of the contendings of Horus and Seth, they challenged each other to race with two stone boats and the one, who will win, will rule the country. In this competition, Horus depended on a trick. He made a wooden boat and painted it in plaster to resemble stone while Seth made a stone boat but his boat sank. Seth transformed himself into hippopotamus to sink a boat of Horus. Here Horus harpooned the body of Seth (Griffiths, 5459).

The harpooning representations appeared since most ancient times (Naqada I period) on the pottery and the handles of knives. The harpooning and hunting representations of crocodile appeared because it was regarded as one of evil symbols (Said 1997, 103). This was confirmed by harpooning and hunting scenes of crocodiles (أنرف، 85-83) in the Old Kingdom.

Then this developed into harpooning rite of crocodile (which associated with the deities) which appeared in the Ptolemaic Egyptian temples and increased in the Graeco-Roman period. In this rite, Horus or the king executed the harpooning as an indication of defeating Seth and later his son $m g$.

Wepwawet was one of the gods who was depicted using the harpoon. In the stela (Bierbrier1993, 24) dating to $19^{\text {th }}$ Dynasty, He appeared in human form with jackal head holding the harpoon standing on shore harpooning the crocodile while a person got out the water and fled from the crocodile. This 
person may be the owner of stela which was dedicated to the god Wepwawet who was regarded as the savior for him as the accompanying text referred:

$w p w 3 w t n b i 3 \breve{s} d$

"Wepwawet, the lord of adoration, the savior" (66-64 2012 ماريان)

The most common association with the god and the harpoon is the association of Horus with it.Through times, this association developed from the myths of birth of Horus and the contendings of Horus and Seth in his different forms. The myth referred to birth of Horus son of Isis at Khemmis in the Delta and during his youth, Horus was attacked by Seth so the god Re sent "Horus Behedety" to aid him. Horus Behedety came in his boat carrying his harpoons. In the beginning of battle, Seth transformed himself into hippopotamus and his followers into crocodiles and at Elephantine, Horus defeated them. This myth contains the scenes of Horus harpooning Seth forms representing crocodile and hippopotamus (Säve- Söderberg 1953, 26).

Horus was also depicted on the southern wall of the Hibis Temple in human form with falcon head and human arms while the rear part of the bird was standing on the crocodile and harpooning it and holding ankh sign in his other hand (Kakosy 1981).

The god Ounty was one of the deities who associated with harpoon. He was worshipped in Abydos, Mendes and Busiris and also associated with the magical texts (Arafa 2011, 259-278).

\subsection{Bows, Shields, Arrows and Swords:}

These weapons were the most ancient weapons which were known in Egypt and associated with some gods. Arrows, bows and shields were the most ancient weapons which were found with the archaeological artifacts in the جيفري، ( 89). In the royal cemetery of Abydos, They were also found on mud sealing which carried the names of $1^{\text {st }}$ dynasty kings from Narmer to Den. On it, Horus appeared holding what seems like a shield and mace (جيفري، 82) (fig. 11a). A text, which was registered on the wooden label of oil jar from the equipments of king Aha tomb in Abydos, showed the visit to the temple of goddess Neith in $1^{\text {st }}$ dynasty period (3000 B.C). In the court of temple, the symbol of goddess

Neith $\square$ Wt $(\mathrm{Nit})(\mathrm{Wb}$. II, 198, 9), which consisted of two crossed arrows and bows mounted on a pole (Gardiner, 503), appeared. "Mistress of bow" and "ruler of arrows (i.e. one who controls the arrows)" were two of her titles. She was local goddess. Sais (Sa el-Hagar) [today in El Gharbaya Province] was the center of her worship. She was known as a goddess of war and represented in human form holding the tools of war.

Since the $2^{\text {nd }}$ Dynasty, the most ancient representation of Neith found on a pot and her shrine was also represented on ivory piece from Abydos ( عبد الحليم 332 ،2009)(early dynastic period) (fig. 11b).

As a warrior-goddess, she was described as an eye of Re since the Old Kingdom and the Greeks associated her with their goddess Athena because of her warlike aspect (Wilkinson, 157). 
She was placed over her head two crossed arrows as most important representation of her in her human form. She appeared holding the w3s Scepter and Ankh sign in the temple of Userkaf at Abu Gurab ( $5^{\text {th }}$ Dynasty). As a warrior-goddess, she was also represented holding the bow and the arrow (Wilkinson, 158).

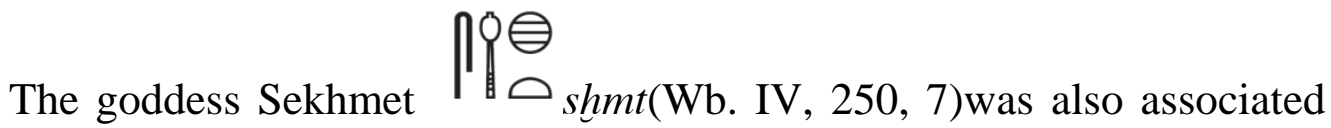
with the arrows. The popular beliefs mentioned "the Seven Arrows of Sekhmet" which was believed to be the cause of bad luck and were thrown against the cosmic enemies by Sekhmet (إيفان، 46). There were many spells to protect against them including the spell calling:

"Book of the last day from year" which were registered on a piece of cloth and tied around the neck in the days of possible dangers at the end of the year (Wilkinson, 181-182).

Sekhmet was regarded as one of goddesses of war which was often represented in a lioness-headed woman form (to be suitable for her strength) wearing a solar disk and uraeus over her head. She was sometimes represented with raised arms waving with a knife and wearing red tight dress (Lex, 323333).

As we have seen, the two goddesses of war, Sekhmet and Neith, associated with the arrows for the first one and two crossed arrows and the shield for the second one (Hall 1994, 55).

It seems that the god Seth also associated with arrows because there was a scene in which Seth taught the king Tuthmosis III the archery and using the arrows(Wilkinson, 199) (fig. 11c).

Later, many gods played a role in keeping guard over the important places in the temples such as the god $m g 3($ (ماريان 2012)who was mentioned in the list containing 119 gods who guarded on the northern wall in the Mammisi of Dendera temple. In this scene, the god $m g 3$ was represented with a falcon head wearing Atef-crown and arming with a sword and two arrows although his original aspect was in a crocodile form(Daumas 1959, 140).

\subsection{Scimitar (Sickle) $\square \smile H p \check{s}($ Gardiner 1973, 583):}

It seems like a sickle but differs in that its sharp blade is external(Schenkel, 819) and sometimes has a pointed end which can be used in the stabbing(Carter 1934). Hpš was made of bronze while its handle was made of ivory or wood(Stuatliche 1972, 52). Sometimes it was adorned with some symbols such as lotus flower; its shapes were developed and sometimes were carried symbols of gods(L ̈. III, 819) as it is shown (in fig. 12a).

The word Hpš indicated to the foreleg of bull and the meaning of strength(Wb. III, 269, 1) so this sword associated with the gods of war who held it in their hands since the $18^{\text {th }}$ Dynasty such as the god Montu, Amun and Baal(Wb. III, 269, 3) and the king received it from the gods such as Amun, ReHorakhty(LÄ. III, p. 822), etc. when he entered the battles with the enemies. 
It appeared as a weapon since the New Kingdom and used as a symbol of authority in the Near East (fig. 12b).

It is noted that the sword and two arrows were weapons which connected with the clash(Wolf 1926,. 73) but the sword appeared in later period relatively comparing to other weapons(Yadin 1963, 10).

It is believed that $M g$ 3 used some of these weapons to secure his entry to Mammisi to protect the divine birth of the god Horus; Especially $M g$ 3 was mentioned in the list which was included 119 protector gods and with regard to a son of Seth(Leitz 693-695) so he played his same contradictory role as one of the evil gods and at the same time he protected and secured the journey of Rebark in the Underworld by stabbing the snake Apophis and this was the same role which was played by his son in protection in Mammisi.

The name of god Bes was also associated not only with knives but also with sword(Zandee 1960, 82-84) because Bes was regarded as one of gods of protection so his name may be derived from the verb $b s 3$ "to protect" and a symbol of protection $s 3$ sign was among his symbols but he was also regarded as one of gods of war so he used the knives and swords $h p \breve{s}$; and later it was known an offering of the sword $\check{s} p h p \breve{s}(\mathrm{~Wb}$. IV, 533, 6-7).

The goddess Waset (Wosret) was one of the goddesses who associated with the bow and arrows. She was depicted in the human form holding her weapons in the New Kingdom scenes(Wilkinson, 169) (fig. 13).

\subsection{Battleaxe 940 ntryt(Wb. II, 357, 12):}

The battleaxe was used as a weapon which was made of flint since the early ages, probably since the Mesolithic or Neolithic Periods. It was a weapon which had a sharp edge and was tied with a wooden handle by strips of leather. At the beginning, the aim of its use was logging the trees and slaughtering the animals and its owner became the strongest one and the most respectable one then it was used as a divine symbol after replacing its head of flint to the metal since the predynastic period(جيفري سبنسر، 108) (fig. 14 a,b). In the Egyptian hieroglyphs, this shape 9 became reading $n t r$ which means god and associated with the strength and ability(95-92 والاس 92). The battleaxes were used in the fighting; in the scenes of Inti tomb at Deshasha(Show 32), they appeared in the hands of Egyptian soldiers during their raid on Asian Nedia fort with other weapons which were used in this raid.

The god Wepwawet (opener of the ways) was one of the gods, who associated with the war and the axe which was used in the opening mouth ritual to the deceased one(ع36 (علد الحليم).

\subsection{Fire and Flames $s \underline{d} t(\mathrm{~Wb}$. II, 319), $n s r(G a r d i n e r, 612)$ :}

The fire uses in the Ancient times and the present as a weapon of intimidation and torture. In the religious books, which depicted the various stages of torture in the afterlife, the tortures were thrown inside the fire where the fire boiled pots existed (fig. 15). 
The Egyptians imagined that the hell was "an immortal fire which was not extinguished" and that the tongues and eyes of the tortures uttered the fire, as well as the knives that they hold and the snakes, which crawl in the eternity, breathe incendiary breathes on the sinners. That was appeared in the $9^{\text {th }}$ hour of the Book of the Gates where the tied and incompetent enemies stand in front of the red tongues of the fire breathing from the mouth of snake which was called "the grand incendiary one" and which was commanded by Horus to spit the fire on enemies of his father to burn their bodies(211-208 2002، إريك 2).

Inside the center of hell, The fire lake whose water is ablaze with fire is in the bottom of the god Sokar's residence in the $5^{\text {th }}$ hour of the Book of Amduat and in the $11^{\text {th }}$ hour of the Book of Amduat, there is with the fiery pits the being which was called "the one which is above his boiled pots". It is "the owner of boiled pots" in the hymns of Re.

In the $5^{\text {th }}$ section of the Book of Caverns, the boiled pots are appeared beside the texts recording the sun-god orders to his servants, saying:

"O the creature Shepen, the Uraeus is above your flame,

$\mathrm{O}$ the one who breathes fire in your boiled pot

which contains the heads of the enemies of Osiris,

Throw your flame in your boiled pot

to cook the enemies of the lord of eternity

$\mathrm{O}$ two snakes which spout the flame and fire

Breathe your flame and increase the blaze under this boiled pot

which contains the enemies of $\operatorname{Osiris}(212$ إريك،

The fire and flame were known for the torture and intimidation. The goddess Wadjet was the one of the deities who associated with the flame and was worshipped in uraeus form which was regarded as her divine symbol since the ancient times(Fischer \& Werner, 907).

According to the solar myth, she was the eye of god Re which transformed into rising uraeus. The god put her on the front of his head to rule the world. She perished and burned the enemies of her bearers by her fiery voice and prevented everything which is harmful from her bearer.

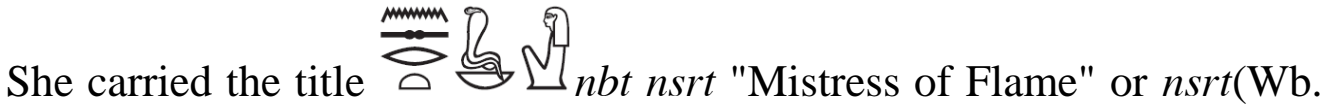
II, 353).

It was believed that this title was carried by the goddess Wadjet since the ancient times because nsrt means inflamed of fiery snake(Sethe, 12), (Frankfort, 176).She was put on the front of the king in Uraeus form as she was on the front of the god Re before that to protect him against his enemies عزة) (245،1997.

\section{Incorporeal Weapons:}

Not only did the Ancient Egyptian deities use their physical weapons such as: arrows, harpoons and knives for attacking, defending and clashing since ancient times, but also there were other ways to attack and protect such as the magic, protection by stretching wings, hands, twining (encircling), bullying 
and intimidation by the names and horrible shapes and using the demons or dangerous beings to punish some persons.

\subsection{Magic:}

Magic forces played an important role in the religious beliefs of the ancient Egyptian. Magic was associated with some deeds, rituals and incantations. Some Scholars believe that the god Heka embodies the magic and the name $h k$ s means the magical deeds or the hidden ways to achieve the things(صفوت 2012، 69 ).

The magic was regarded as the gifts of the creator God. Khety mentioned in his instructions for his son Merikare that the god made the magic for them (humans) as a weapon to prevent the disasters(Lichtheim 1973, 97).

Eleven Spells remain on a statue base(Klasens 1952, 1) for a protection against scorpions and snakes. The $4^{\text {th }}$ and $5^{\text {th }}$ spells are associated with the goddess Isis and her magic. The $4^{\text {th }}$ spell mentioned: $h k 3 w \ldots . . . "$

"I am the goddess Isis, Mistress of Magic $h b t h k 3 w$, I make the magic irt

The $5^{\text {th }}$ spell mentioned:

"I am Isis, Mistress of Hmnis, who make poignant words in the hidden place. Geb put his magical forces under my command to protect my son Horus, to shut the mouth of each snake, to take away each lion in the desert and each crocodile in the river and all the snakes which bite by their mouths from him while I prevent the poison in a moment, so its heat was prevented. I'll give to him the air which is a short breath by the magical force of my spells "صفوت) (77،2012.

Isis was depicted on a limestone stela in a composite form which consists of a body of female hippopotamus, human face and tail of crocodile. $3 s t n p 3$ st 3 was one of her titles. Her composite form referred to her magic and her protection against the bites of reptiles and harmful insects(Bruyere 1950, 515-522).

The magic was known by the ancient Egyptians since ancient times. Some goddesses such as: Isis, Nephthys and Wadjet were associated with the title "great one of magic"wrt hk3w (Wb. I, 326, 6).According to the myth(إيمان،172), Isis was able to make Re tell her his secret name. Isis used also her magic when she accompanied with the god Re in his bark in the Underworld to take away the danger of the snake Apophis(Pleyte, Rossi, 1869, 13 ff), (Gardiner 1935).

Not only did the god Bes depend on his weapons which were held in his hands such as: knives, swords and sign $s 3$ "symbol of protection", but he also depended on his ugly shape in a scare and prevention of evil beings harm as well as he also depended on the magic so the magical knives appeared since the Middle Kingdom and Bes was depicted on it naming the warrior ' $h$ ' $w t$ to give the protection to the humans against the evil animals such as crocodiles, hippopotamus and reptiles(25، 2006). 
There are a lot of spells which confirms that the deity will protect the one who need the help against the harmful animals such as:

"Tie the crocodiles in the river and the lions in the desert and all the snakes".

Which was repeated on several stelae, such as: CG.9404, CG.9402 which were preserved in the Egyptian Museum(Daressy 1903, 23 ff).

Wadjet was called wrt hk3w "great one of magic" because she was the eye of the sun-god and adorned the front of the king. She was the Mistress of house fire (flame). All of that were weapons which were used by her to protect the king. w3drt wrt hlk3w nbt pr wr nbt pr nsr

"Wadjet, Great one of magic, Mistress of the great house, Mistress of the house of fire (flame)".

Some stelae which were called "magical stelae of Horus"(Sadek 1997) were appeared. The magic was used in these stelae to treat for bites of scorpions, snakes, crocodiles and harmful animals. In the beginning, the Pyramid Texts were including these spells since the Old Kingdom and also some statues appeared in this period representing a sitting or standing person as a god Horus who stands on the crocodiles. These statues developed from the Old Kingdom to the Graeco-Roman period(Rinter 1989, 105), (Kakosy, 60-61).

There were also the stelae of the god Shed which appeared since the $18^{\text {th }}$ Dynasty which depicted him as a standing one on the crocodiles and holding in his hands a lion, gazelle and snakes which symbolized the forces of harmful evil or the god Seth. The correspondence between Horus and Shed led to the appearance of "Horus-Shed"(Said 2009, 449-460)(fig. 16).

These magical texts, which associated with the protection, increased in the Late Period until the Graeco-Roman period and were recorded on the stelae which were covered with the magical spells on its back side completely and on its front side with a young man deity carrying above his head an old man deity while the young man deity was standing on two crocodiles holding in his hands a group of snakes and scorpions, and harmful animals(عنايات، 314). These stelae were used to pour water on it then the water was drunk or put inside the water then the water was drunk if the size of these stelae was small.

Horus Behedety was one of the deities who were depicted on it. Amulets were found representing harpoon with a falcon head of Horus (protector). These amulets were kept with the deceased ones in their tombs to protect them in the Underworld against the forces of evil(Griffiths, 60), (Petrie, 1914). Amun was represented in human form standing on two crocodiles and holding in his hands snakes which wrapped itself around his hands. Ptah was also represented as a dwarf standing on two crocodiles and a scarab above his head.

The gods used the forces of magic in defense, protection and punishment. An ostrakon from $18^{\text {th }}$ Dynasty referred to this punishment which transforms the sighted one into the blind one. This ostrakon referred also to the power of Amun-Re and his strong revolution which transformed day into night(Posener 1974, 201-202). This was also mentioned on a stela of "Nefer 
Abu" which was preserved in the British Museum Inventeire no 589from Deir el-Medina(Ramesside Period). He mentioned that:

"I swore a false oath of the god Ptah, the Lord of Truth so he makes me see the darkness in the day (i.e. he became blind) ...."(Posener 1974,195-210).

Also the deities used the demons or dangerous beings to punish some persons so some persons, who wanted to protect themselves against these punishments which were referred in some demotic papyrus which was dated to Ptolemaic period(Thompson 1940, 68-70), dedicated themselves, their sons, grandsons, and servants to serving one of the goddesses and pledged to pay a monthly stipend to her priests to protect them(إيفان 1999، 290). Because there were some diseases which were not known its causes such as fever and headache, they believed that its causes were the punishment of the gods(Ghuliaungi 1983, 11), so some scholars believe that the ancient Egyptian medicine depended in a lot of it on the magic(13 2001، ليلى (Satis).

The goddesses Anuket (Anukis) and Satet (Satis) were two of goddesses of protection. Their role was confined to prevent the dangerous disease to reach some parts of the body such as the front, nails, lungs and kidneys, so Anuket was called "Mistress of Nails". Here the protection was magical(أسامه،295).

\subsection{Using the wings and hands as an Incorporeal Weapon for protection:}

The wings were the most ancient incorporeal weapons which were used in the care and protection. When Isis collected the body parts of his husband Osiris with help of her sister Nephthys, she made wings for her sister and herself by using her magic. Then they covered the body of Osiris with these wings for fear of being seen by Seth so they are goddesses of protection(Griffiths 1994, 255-264). They were often depicted as goddesses of protection on the coffins or on many of walls of tombs in the New Kingdom(Münster 1968, 201).

Since the $3^{\text {rd }}$ Dynasty in the scenes of the southern tomb of king Djoser (Zoser), Horus appeared in a falcon form flying above the king to protect him stretching one of his wings for the protection and offering $\breve{n}$ sign to the king by the other wing(زكية 1987، 207).

The goddesses of protection like Nephthys(Wilkinson, 159 ff) didn't take one aspect for protection but they took several aspects and forms. She was not only depicted with wings on the coffin for protection, but she, Isis, Neith and Serket (Selket, Selkis)(Robins 1984, 21-22)were also depicted in a snakeheaded woman form breathing poison in the bow of sun-bark for protection. Nephthys was depicted in the snake (uraeus) form in front of the $12^{\text {th }}$ gate of the Book of the Gates. That correspond with her titles such as: Great one of magic and Mistress of the protection(109-54، جابر). Here it is worth mentioning that the statue of king Khefern (Khafre), which was preserved in the Egyptian Museum no J.E. 10062, has Horus in a falcon form behind its head stretching his wings for protection(Asmann 1972, 115-139) (figs. 17a, b). The four 
goddesses of protection, Isis, Nyphthys, Neith and Serket protected the shrines, throne, tomb and canopic jars(عبد الحليم، 310).

The four goddesses appeared while they were protecting the gilded wooden naos of Tutankhamen which contained the stone chest where the eviscerated organs of the king were preserved. They were represented as women stretching their arms to protect the naos. Each of them has carried her symbol on top of head. Their four statues made of gilded wood. The Naos is preserved in the Egyptian Museum (it was found in the tomb of Tutankhamen New Kingdom) (fig. 18).

Mhn appeared to protect the god Re in his night journey in the Underworld by wrapping around him (fig. 19) and the protection associated with using $\check{n} n$ sign. This word was derived from the verb šni which means "to encircle" and according to Meeks(Meeks 1981, 378-439), this sign referred to a symbolic form of protection.

\section{Some weapons of foreign gods in Ancient Egypt:}

The foreign deities entered Ancient Egypt in ancient times because of several reasons, including some of them who came with Hyksos or merchants through the ways of trade between Egypt and the countries which surrounded it.

\subsection{Anat(سلوى 1995):}

Towards the end of the Middle Kingdom, the goddess Anat entered Egypt; her name appeared within the names of Asian servants(Hayes 1955) and some kings of Hyksos.

In the Papyrus Chester Beatty I (Papyrus Chester Beatty I, Verso III, 35), The goddess Anat and goddess Astarte were considered to be among daughters of Re; They were given the god Seth and became among consorts of $\operatorname{him}($ Gardiner 1911, 15).It was known that the care and concern of the Ancient Egyptian Kings for the Syrian gods was because of their feeling and faith in their strength(Staelemann, 17) and this is the reason which made them among the gods of war in Egypt.

She played an important role in rescuing and helping the kings and others as a goddess of war; this role mentioned on the ostrakon from the reign of king Ramesses IV:

"Thoth with you and we find him (in the help of) Anat $\underline{\text { Dhwty }} m$ di.k $h n^{\mathrm{c}}$

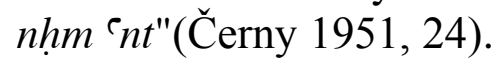

In the mythical texts of Ugarit, Anat had a military nature so she was "Powerful Anat" and "Anat with aggressive power"(سلوى 1995، 37), may be this was one of the reasons for which were regarded as one of the warriorgoddesses in Ancient Egypt.

The Goddess Anat occupied the first place with some Egyptian gods in the time of $19^{\text {th }}$ and $20^{\text {th }}$ Dynasties although she was an Asian goddess. The King Seti I associated his warrior chariot with the name "The goddess Anat" and the King Ramesses II called his daughter name "Bint-Anat" (daughter of Anat) and called his sword name "Victorious Anat". It is probably that she was 


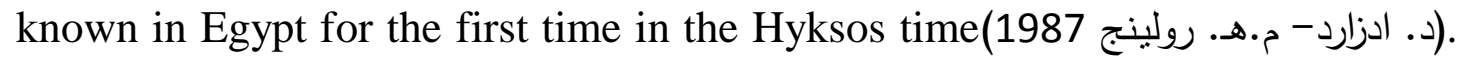
She was one of the warrior-goddesses in the New Kingdom and "King's shield in his war" was one of her titles. She had a place for her worship in the temple of Ptah at Memphis and the King Ramesses II built a temple for her at PerRamesses. She was represented in a woman form holding a shield, harpoon (spear) and battleaxe (axe) and often depicted with one arm raised holding one of the weapons(Wilkinson, 137).

The myth of Aqhat showed that Anat associated with the bow and arrows and used them finely(سلوى 1995، 151).

She was also considered a shield for kings and associate with the shield as a weapon of protection as well as she carried the harpoon and she used it finely.

3.2. Astarte $\underset{\infty}{\infty}\}$

Astarte was an Asian goddess which was worshipped in Egypt in the New Kingdom. She was considered as a goddess of war and wife of Baal, worshipped at Memphis and represented on Egyptian Antiquities in a lionessheaded woman form surmounted by the sun-disk holding a shield and mace in her hands or a harpoon in one hand and an arrow in the other riding a horseback(Leclant, 499-509), (Hall 1994, 73).

In one of the texts of temple of Medinet Habu, Astarte was described as the shield which protects the king in his wars: "Astarte for him as a shield šstjrt n.f m ikm".

Astrate was known as the goddess which protects the worrior chariot; there are a relief on a warrior chariot of the king Tuthmosis IV which described the king as a hero on his chariot like Astrate.

\section{Some Gods of War in Ancient Egypt:}

The gods participated with the kings in securing the borders, hunting and pouncing on the enemies since the ancient times, this appeared on their antiquities such as a lions hunting palette which portrayed a fierce battle on one of its sides. In the middle of battle, an angry lion appears; in front of it, a figure with a long dress appears, this figure may be represented an Egyptian goddess; it drives a naked prisoner except from the pod genitals before it. The arms of prisoner are tied behind him. Above the lion, two standards of the gods Horus, Thoth and figure of Ibis appeared; the two standards have human arms leading a prisoner who has a thick beard and curly hair(مروة 2011، 15-16).

\subsection{Seth(Te Velde 1986, 37-38):}

He appeared on the standard in the scenes of macehead of the king Scorpion from the Predynastic Period because the king takes his power from the power of god. Seth also appeared teaching the archery and use of the bow to the King Tuthmosis III in the relief of $18^{\text {th }}$ Dynasty from the temple of Karnak(Wilkinson, 199).

His strength came from his violence and evil, his violence came since his birth and dash in violence pyr. 306. The deceased ones request the help 
from him in the Underworld against the forces of evil(CT VI, 167). In one of his statues, he appeared in a human form raising his hands in a position to use his weapon (animal head)(Schorsch 2009, 177-200).

4.2. Montu(Wilkinson, 154):

He was known as a god of war in Ancient Egypt and Mntw nb w3st "Montu, the lord of Waset (Thebes)". He was represented in a falcon-headed human form surmounting a sun-disk, two feathers and uraeus. He was also depicted with the head of bull in the Late Period. In the New Kingdom, some kings were described that they are "fighting like the god Montu in his strength"(Wilkinson, 203).

Text, from the reign of the king Seti I, mentioned that the king held some of military tools which were used by some gods to imitatethem, so he said:

$$
\text { "dpw.n.f šrr } n \text { Mntw psdt } n \text { B3stt" }
$$

"It is your name with arrow of Montu and bow of Bastet"(Hassan, 104)

4.3. Sekhmet

Her name means the Powerful one. She is a powerful, dangerous and protector at the same time because one of the most important titles of her was "Eye of Re irt $R^{\text {r" }}$ (Leitz, 557). She breathes fire against her enemies so the Egyptian kings adopted her as a military patroness. Perhaps, the most important evidence of her power was her representation in a lioness-headed woman form with red dress which is coloured red(Wilkinson, 181).

The aspects and representations of the goddess in a form of lioness confirmed her strength and ferocity. Some texts of Middle Kingdom mentioned that the goddess participated with the king in his wars. The king made himself resembling the goddess Sekhmet in confronting his enemies such as King Senwosret III who made himself resembling the goddess Sekhmet in a text saying:

$$
\text { is wi šhmt pw r hft (hr) hftyw }
$$

"Indeed I am Sekhmet in the face of the enemies"(Griffith, 26)

In another text, he said:

"He shoots the arrows like Sekhmet sti.(f) š̌r mi shmt"(Griffith, 7)

The Texts show that the goddess Sekhmet did not only use the arrows in the war, but also she used the flame of day (embers of the fire) to burn her enemies as it was mentioned in Coffin Texts. She sends her hot breathes and throws fire on the enemies as well as she sends her assistants with the plague and epidemic against the enemies(De Buck, A., CT., IV, 329 k).

It is possible to say that the aspects of lioness goddess with uraeus were considered as an eye of Re and eye of Horus when they protected the king so they played an important role in the war to protect the king, thus we find that some of other goddess integrated in the form of a lioness since the Old Kingdom. In one of the Coffin Texts, the goddess Wadjet was resembles fire which considered one of weapons of goddess using to eliminate the enemies such as: 


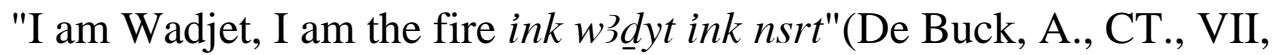
$166 \mathrm{~g}$ )

In the New Kingdom as a result of increasing the conquests and military and martial activities of the kings of this period, some goddesses integrated with the goddess Sekhmet such as: Mut and Bastet and they were known as goddess of was as the texts referred to them such as text from the reign of the king Amenhotep III which described the goddess Mut as the Mistress of Nine Bows:

\section{"Mut ǐšrw mw3st hnwt psd \\ "Mut Isheru in Waset (Thebes), Mistress of Nine Bows"(Spieflberg, 43)}

\subsection{Amun:}

Under the standard of Amun and with his help, Kings of Thebes won the liberation war against the Hyksos. In a text, the Theban king Kamose says $\left(17^{\text {th }}\right.$ Dyansty):

"......... Then I sailed downstream to the north to stop the Asians according the orders of Amun who has the right advices"(241-240، 1970،

On the southern third pylon in the karnak temple, the king Tuthmosis I appeared standing in the front of the god Amun and behind him Mut and Khonsu holding the royal mace in one of his hands while he was raising another hand toward the god Amun. Above the god Amun, there is the following text:

\section{di.n (i) $n . k n b$ nht $n b$ hr.i}

"I give you all the strength, all the victory from me"

In the Harris Papyrus, King Ramesses III prays to the god Amun for giving his son after him the victory and foreign countries, so he says:

"Make him holy than any king, great like your veneration as a god of Nine Bows, make his body prosperous and be young every day while you are Re behind him every day, put his sword and his military staff over the heads of Bedouins and fall in fear of him like Baal, expand the borders for him to the maximum as he desires, let the lands and countries in fear of him" 1970، محمد) (205.

Amun gave his sword to the king to cut off the heads of his enemies; it seems that the god Amun participated actually in the battlefield. In one of the scenes of the temple of Medinet Habu, the standard of Amun represented in a chariot in front of the chariot of the king Ramesses III and Amun offers the $H p \check{s}$ sword to the Pharaoh with one of his hands and the tied foreign countries with the other hand(241-240، محمد 1970).

The naming the army divisions and brigades with the names of gods also referred to that; the most important of these name was Amun. This appear in an inscriptionon the rocks of Konosso Island near Philae which mentioned that after his knowledge of the intentions of Nubians to revolt against Egypt, the king Tuthmosis IV came to the temple in peace in the morning and requested the presence of the rule of gods "Amun" to give him advice on his going, then the king went to conquer the Nubians in Nubia. 
The scenes, which showed that Amun offers the Hpš sword to the King with one of his hands and leadership of the tied foreign countries with the other hand, supported that(Breasted, 328), (محمد، 241).

\subsection{Anuket (Anukis):}

Anuket was known as a goddess of protection and warrior-goddess; this appeared in her titles, tools and locations. ' $n k t$ t $n b t$ t3-šm $i$ "Mistress of Southern Countries", 'nkt nbt stt Anuket "Mistress of Sehel" and 'nkt nbt 3bw Anuket "Mistress of Elephantine" because she was a mistress who was responsible for these places and southern regions. She also was a goddess of protection and defense and also a daughter of Re; these were the reasons of strength of Satet (Satis) and her.

\section{htp di nisw Hnm Stt ' $n k t$ s sti Re}

"A gift which the king gives (to) Khnum, Satet and Anuket; the two daughter of $\mathrm{Re}^{\prime}$

She was represented in a human form with a crown of feathers but sometimes taken a determinative of uraeus(Valbelle, 1981, 104 (24), 128 (49)).

She also associated with the bows, arrows and wings(أسامه 2002).

\subsection{Horus(Schenkel, 14-25):}

Horus was one of the most ancient deities which appeared in the scenes and mentioned in the religious texts. He was associated with the king since the most ancient times. On the Narmer Palette, which commemorates his victory and the unification of country, falcon-Horus held the head of a man by rope held by his human hand. He also appeared on the ivory comb from the reign of the king Den ( $1^{\text {st }}$ Dynasty) as a falcon sailing in a boat. His names, titles, forms, and the places where he belonged were numerous but he remains the son of Osiris and Isis who played an important role in keeping the kingship and regaining of it from his uncle Seth(Gardiner 1931, 8-26), (Griffiths 1960), (Griffiths, 84-86), thus Horus associated with the king and kingship since the most ancient times. He also was the relation between the gods and the human world in his heavenly form in the falcon form which flies away and his association with the king through his Horus name. In addition to the falcon form, one of the most important forms of him was the human form. His name which means "the one who raises his arms"(Altenmüler, 46-47) was among his names which referred to him as a warrior.

As one of warrior-gods, he played an important role in protection of children in the Mammisi "the Birth Houses"(Doumas, 139).

Horus was also entitled $\mathrm{Hr}$ imi šnwt(Wb. IV, 498, 5)"Horus, Holder the rope"(Velde, 47-48), (Schenkel, 14-25), (Mewcerm 1942); this title may refer that he leads the prisoners and holds them as it was appeared on the Narmer Palette.

$H r$-Wr was also one of his titles(Leitz 2002).Harwer (Haroeris) was the head of triad of Kom Ombo temple, portrayed in a falcon-headed human form; his name means "Horus the Elder" or "Horus the Great one". This form continued until the Graeco-Roman period wearing a roman soldier costume confirming his role as a warrior in all ancient times (fig. 20). 


\section{Conclusion:}

1. The gods who associated with weapons were in full human form or at least these gods held their weapons by human hands even though they have animals' heads.

2. Some foreign deities such as the ones who came from Asia who associated with weapons were taken the same form of the Egyptian deities so all of them have human form.

3. The military campaigns raised the names and symbols of some gods (who associated with the weapons) on the standards to obtain their protection and strength.

4. The forms of protection (protection of gods) did not only confine to the physical weapons, but also it extended to incorporeal weapons such as encircling (twining) by hands and wings to indicate to the protection.

5. Magic can be considered one of the most important weapons which were used by gods.

6. The use of weapons did not only confine to the life, but also it extended to the afterlife, that is confirmed by the religious texts and scenes which associated with the afterlife such as: Book of Amduat, Gates, Caverns and others.

7. The most important incorporeal weapons were staves, spears, knives, arrows and shields.

8. The forms and names of staves which were used in ancient Egypt were numerous and associated with the deities and kings and developed according its use. The types of staves were:

a. The staff $m d w$ which was used to smite the rebels and enemies. The mace was used which can be seen on the Narmer Palette.

b. The staff $\supsetneq$ ' $w t$ which appeared with the god Andjety was as a staff of the shepherd. It was tall and bent staff and the staff of shepherd.

c. The staff $h k 3$ (scepter) was an advanced form of the shepherd' staff because its bent edge became more specific and it became shorter. Thus it became more symbolic and permanent in the hands of the kings and gods.

d. The staff $w 3 s$ (scepter) was one of the most ancient known forms since the most ancient times. It was also called $\underline{d}^{\top} m$ when it was corrugated. It associated with the god Seth and indicated to the strength and authority so it associated with the kings and gods.

9. In the beginning, the branches and stems of trees were known as staves and used in smiting then a strong head was added to it to obtain the best result like the mace which was represented since the most ancient times. In the beginning, the staves associated with some gods such as: Seth and Andjety then associated with many gods. 
10. The most important staves were $w 3 s$ and $h k 3$ which associated with the strength and dominion then the kings inherited them from the gods.

11. The scenes show that the long staff was used to control the movement of enemy while smiting him by the mace.

12. The flame (fire) and knife which were two of the weapons of gods were most common in using in the scenes of the Underworld.

\section{References:}

\section{First: The Arabic references}

أحمد محمد عبده، المعبود إينجرت منذ بداية ظهوره حتى نهاية الدولة الحديثة، رسالة

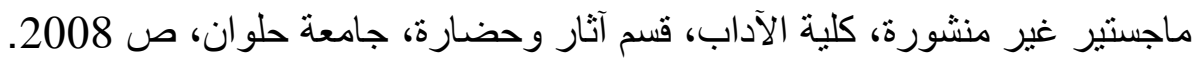

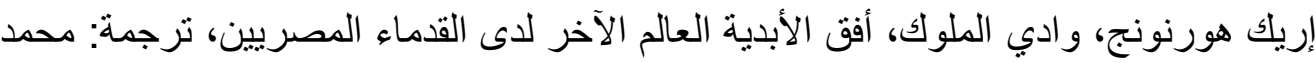

$$
\text { العزب موسى، القاهرة، } 2002 .
$$

أساطير معبد إدفو، شرح وترجمة للمتون و الطقوس من المصرية القديمة، ترجمة محسن لطفي السيد، مراجعة محمد صالح، القاهرة، 2003.

أسامه عبد العال علي، المعبودات النوبية في المصادر المصرية المبة القديمة، رسالة ماجستير غير منشورة، كلية الآثار، جامعة القاهرة، 2002.

أشرف زكريا، التماثيل والتشكيلات الحيوانية الطابع في مصر وبلاد الثرقات الأدنى القديم في عصور ما قبل التاريخ، رسالة دكتور اة غير منشورة، القاهرة،

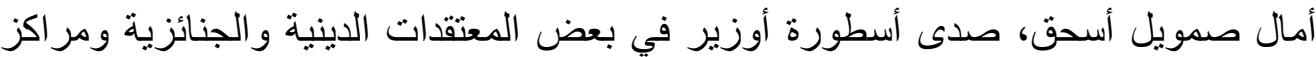

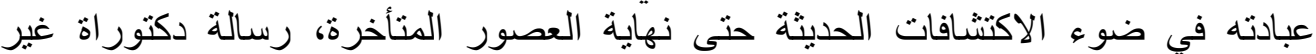

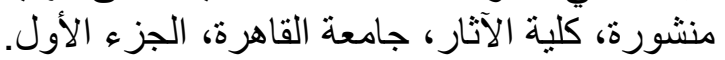

إيفان كونج، السحر و السحرة عند الفراعنة، ترجمة محمود ماهدة الاهر ، القاهرة، 1999. إيمان محمد المهدي، طرز و أشكال مر اكب العالم الآخر في كتابي الايمدوات و البوابات، مجلة التاريخ و المستقبل، جامعة المنيا، كلية الآداب، قسم التاريخ، عدد يوليو 2015.

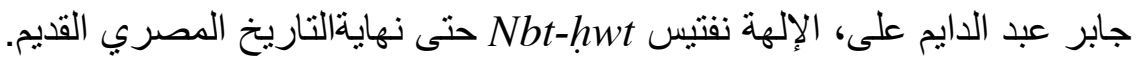

جيفري سبنسر، مصر في فجر التاريخ، ترجمة عكاشنة الدالي، القاهرة، 1999.

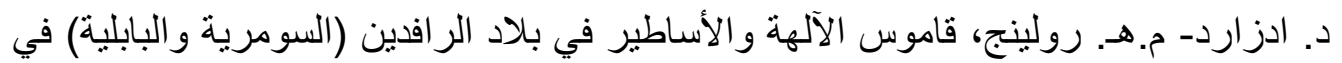

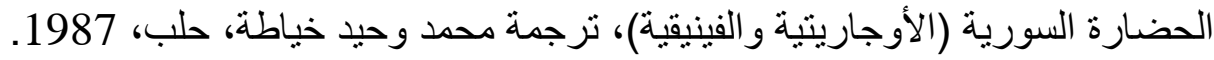

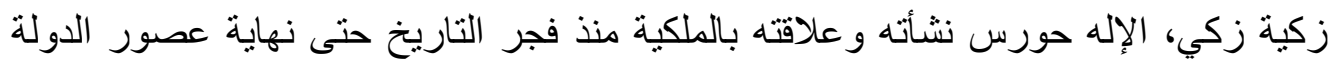
الحديثة، رسالة دكتور اة غير منشورة، جامعة القاهرة، 1987. سلوى أحمد كامل، الإلهة عنات، رسالة ماجستير غير منشورة، كلية الآثار، جامعة القاهرة، .1995

صفوت محمد عبد العاطي، المعبود حكا في الديانة المصرية القديمة حتى نهاية العصر المتأخر ، رسالة ماجستير غير منشورة، كلية الآثار، جامعة القاهرة، 2012.

عبد الحليم نور الدين، الديانة المصرية القديمة، الجزء الأول، المعبودات، القاهرة، 2009. عزة فاروق سيد، الإلهتان نخبت وواجيت منذ أقدم العصور حتى نهاية الدولة الحديثة، رسالة

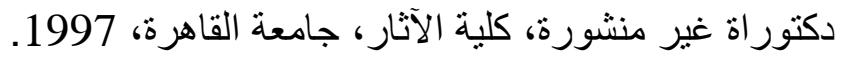




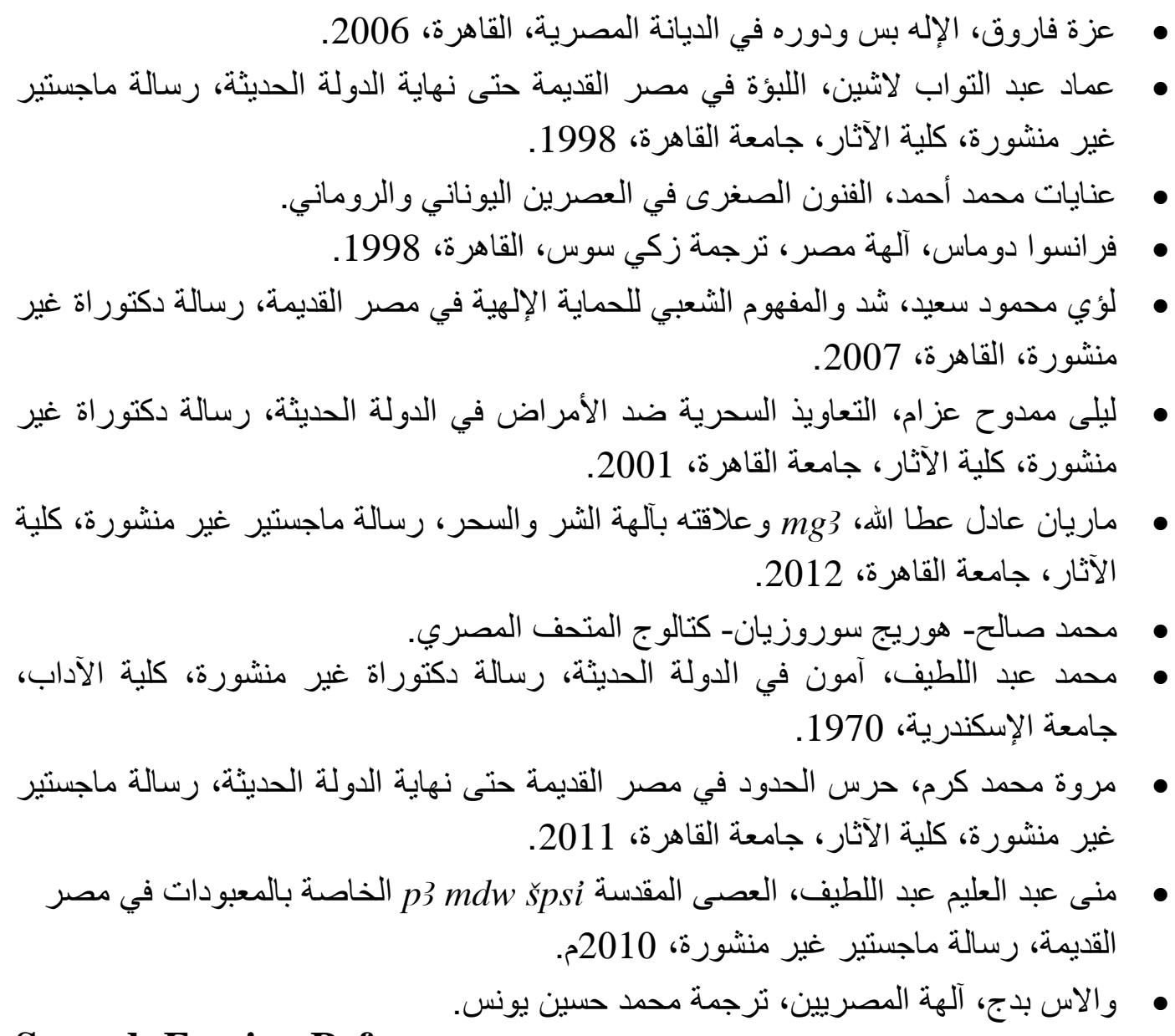

Second: Foreign References

- A. Leahy, "A protective Measure at Abydos in the Thirteenth Dynasty"., JEA. Vol. 75 (1989).

- A.J. Mills, Two Sekhmet Statues at Trewithen in Cornwall"., JEA. Vol. 65 (1979).

- A.J. Spalinger, "A Redistributive Pattern at Assiut"., JAOS. Vol. 105, No. 1, Jan-Mar., 1985.

- A.M. Lythyoe, "Statues of the Goddess Sekhmet"., the Metropolitan Museum of Art Bulletin, vol. 14, No. 10, Part 2; Statues of the Goddess Sekhmet (Oct. 1919).

- A.N. Dakin, "The Stela of Sculptor Sire at Oxford"., JEA., vol. 24 No. 2 (Dec., 1938).

- A.W. Shorter, "Two Statuettes of The Goddess Sekhmet-Ubastet"., JEA. Vol 18, No. 3/4 (Nov. 1932).

- Allen, J.p., the Ancient Egyptian Pyramid Texts, pyr. 1145

- Altenmüler, B., Horus von Linyen (Hrt h̆hw) in: LÄ. III.

- Arafa, N., Enquête Sur le dieu Ounty"., JARCE. 47 (2011).

- Asmann, J., "Neith Spricht als Mutter und Sarg", MDAIK. 24 (1972).

- Bierbrier, M.L., The British Museum Hieroglyphic Texts from Egyptian Stelae, Part 12, 1993.

- Boylan, P., Thoth, Chicago, 1987.

- Breasted, Ancient Records, II. 
- Breasted, J.H., Medint Habu II, The university of Chicago Oriental Institute.

- Brunner, H., "Eine Dark Stele an Upnaat"., MDAIK. 16 (1958).

- Bruyere, ASAE. 50 (1950).

- Buttery, A., Armies and Enemies of Ancient Egypt and Assyria.

- Černy, J., Catalogue des Ostraca Hieratiques non Litteraires de Deir el Medineh, Tome V, (Nos 340- á 456), Le Caire, 1951.

- CT VI.

- D. Valbelle, Satis Et Anoukis, II, Mainz, 1981, p. 104 (24).

- Daressy, M.G., Catalogue Général des antiauitiés égyptiennes du Musee du Caire (Nr. 9401-9449), le Caire, 1903.

- Davies, Kan-Amon, I.

- De Buck, A., The Egyptian Coffin Texts, VI, CT. VI.

- De Morgan, Dahchour, I.

- Doumas, Mammisis de Dendora, 139.

- Edfou I, 2, 302, 13

- F. Daumas, Les Mammisis de Dendara, le Caire, 1959.

- F. Fischer \& H. Werner, in: LÄ. VI.

- Faulkner, Book of the Dead, New York, 1985.

- Faulkner, CT., I.

- Gardiner, A., E.G., Oxford, London, 1973.

- Gardiner, A., Egyptian Grammar, Oxford, 1957.

- Gardiner, A., Egyptian Hieratic Texts, London, 1911.

- Gardiner, A., Hieratic Papyrus in the British Museum II, London, 1935.

- Gardiner, A.H., Chester Beaty Papyrus No. 1, London, 1931.

- Ghuliaungi, P., The Physicians of Pharaonic Egypt, Cairo, 1983.

- Gordon \& Schwobe, "The Egyptian w3s scepter and its modern Analogues uses as Symbols of Divine power Authority., JARCE. 32 (1995).

- Griffith, F., The Petrie Papyri, Hieratic Papyri from Kahum and Gurab, II.

- Griffith, F.I.I., Hieratic Papyri from Kahun and Gurob, London, 1898, text vole.

- Griffiths, J.G., "Horus and Seth"., LÄ. III.

- Griffiths, J.G., "Horusspeer", LÄ. III.

- Griffiths, J.G., "Isis as Maat, Dikaisume and Iustita"., in: Hommages a Jean Leclant, VIII (1994).

- Griffiths, J.G., The Conflict of Horus and Seth, Liverpool, 1960.

- Hall, J., Illustrated Dictionary of Symboles.

- Hamblin Willami., Warfare in The Ancient Near East to 1600EC, London and New York, 2006.

- Hassan, Ali, Stöcke und Stäbe im Pharaonischen Ägypten, MÄS, 33 (1976).

- Hassan, S., Excavation at Giza, VII. 
- Hayes, The Scepter og Egypt, I.

- Hibis III, pl. 4,1

- Hornung, E., Conceptions of God in Ancient Egypt, the one and the Many, New York, 1982.

- Ian Shaw, Egyptian Warfare and Weapons, Uk, 1991.

- Junker, H., Winter, E., Das Geburts Hous des Temples Der Isis in Phila, Wien, 1965.

- K. Sethe, Sonnenauge, p. 12; H. Frankfort, Kingship.

- Kakosy, L., "Das Krokodil als Symbol der Ewigkeit und der Zeit"., in: Studia Aegyptiaea. 7, Budapest, 1981.

- Kakosy, L., "Horus Stele"., LÄ. III.

- Kees H., Der Götterglaube im Alten Ägypten, Leipzig, 1941.

- Klasens, A.,Amagical Statue Base in The Museum of Antiquities at Leiden, Leiden, 1952.

- Lange, K. and Hirmer, M., Ägypten, München, 1978.

- Leclant, J., Astarte, in: LÄ I.

- Leitz, Ch., Lexikon Der Ägyptischen Götter und Götter bezeichnungen, Paris, 2002.

- Leitz, LGG VI.

- Lex, V.

- Lichtheim, M., Ancient Egyptian Literature, vol. I, London, 1973.

- Lurker, M., Götter und Symbole der Alten Ägypter.

- Mariette, Deir el- Bahri, Leipzig, 1877.

- Martin, "Was Zepter", LÄ. VI.

- Meeks, D., Annee Lexicographique, T.2, 1981.

- Müller, Hans-Wolfgang, Ägyptische Kunst, Germany, 1970.

- Münster, M., "Untersuchungen Zür Göttin Isis vom Alten Reich bis zum Ende des Neuen Reiches mit hierog Lyphischem Textanhang., MÄs 11 (1968).

- Otto, "Anediti"., LÄ. I.

- P. Chester Beaty I.

- Paulkner, AECT, II.

- Petie, F., Tools and weapons, London, 1917, pls. XXIII - XXIX, XXX, XXXI, Lex. IV.

- Petrie, W.F., Amulets, London, 1914.

- Picardo, N.S., "Semantic Homicide" and the So-Called Reserve Heads: The Theme of Decapitation in Egyptian Funerary Religion and Some Implications for the old Kingdom., ARCE., 43 (2007).

- Pleyte. W. and Rossi, F., Papyrus de Turin, 2 vols, Leiden, 1869-76.

- Posener, G., Lapiété Personnelle orant Iage a marnien, Reyue d'Egyptologie, 27, 1974, Paris.

- Posener, G., "Les empreintes magiques de Gizeh et Les morts dangereux"., MDAIK. 16, 1958.

- Pyr. 220 b-c 
- R.O. Foulkner, "The Stela of The Master-Sculptor-Shen"., JEA. Vol. 38 (Dec. 1952).

- $\quad$ Rinter, R., "Hoyus an the Crocodiles"., YES. 3, New Haven (1989).

- Rinter, R.K., The Mechanics of Ancient Egyptian Magical Practice, Chicago, 1993.

- Robins, G., Isis, Nephthys, Selket and Neth represemted on the sarcophagus of Tutankhamun and in four free- Standing Statues found in KV. 62, GM. 72 (1984).

- Sade, A. I., Popular Religion in Egypt during the New Kingdom, Hildesheim, 1997.

- Said, L.M., "Enemies of the Gad or enemies of the State, on the Late Hor-Shed Stelae? (Stela: J. 68115 in Museum of the Bibliotheca Alexandrian) the Horizon Studies in Egyptology in Honour of M.A. Nur El-Din (10-12 April 2007), vol. III, 2009.

- Said,A., "Göttergloube und Göttheiten in Vorgeschichte und Fruhzeit Ägyptens, Dissertation, Fakultat der Ärchäologie (1997).

- Säve- Söderberg, T., On Egyptian Representations of Hippopotamus Hunting as Reliyious Motive, Uppsala, 1953.

- Schenkel, W., Horus, in: LÄ. III.

- Schenkel, W., Krummschwert, in: LÄ. III.

- Schorsch, D. and Wypyski, M,T., Seth, "Figure of Mystery"., ARCE. 45, 2009.

- Show Ean, Egyptian Warfare and Weapons, London, 1991.

- Spieflberg, W., Die Bauinschrift Amenophis, oul der Flinders Petxie Stela, Rec. Trav 20.

- Staelemann, R., Syrisch.

- Te Velde H., Seth, The gad of Confusion A study of his Role in Egyptian Mathology and Religion, Brill, Ley de, 1967.

- Te Velde, H., "The Egyptian God Seth as atrickster"., JARCE, 7, 1986.

- Theodore J.Lewis, "Cathtatu's Incantations and The Use of Divine Names as Weapons"., JNES. 70, No. 2 (Oct. 2011).

- Thompson, H., Two Demotic Self Dedications, JEA. 26, 1940.

- Van de Walle, "Le Pieu Sacré D'Amon"., Aror 20, 1952.

- Vercutter, "Apis", LÄ. I.

- W.A. Ward, "The Hiw-Ass, The Hiw-Serpent and the God Seth"., JNES., vol 37, No. 1, (Jan., 1978).

- Wb. I.

- Wb. II.

- Wb. IV.

- Wb. V.

- Wilkinson, R., The Complete Gads and Goddesses of Ancient Egypt.

- Wolf, W., Die Bew affnung des altägyptischen Heeres, Leipzig, 1926.

- Wolfang Helck, "Messer"., LÄ. IV.

- Yadin, Y., The Art of Ware fare in Biblical Lands, London, 1963. 
- Zandee, J., Death as an Enemy according to Ancient Egyptian Conceptions, Leiden, 1960.

\section{Third: Web sites}

- www.touregypt.net

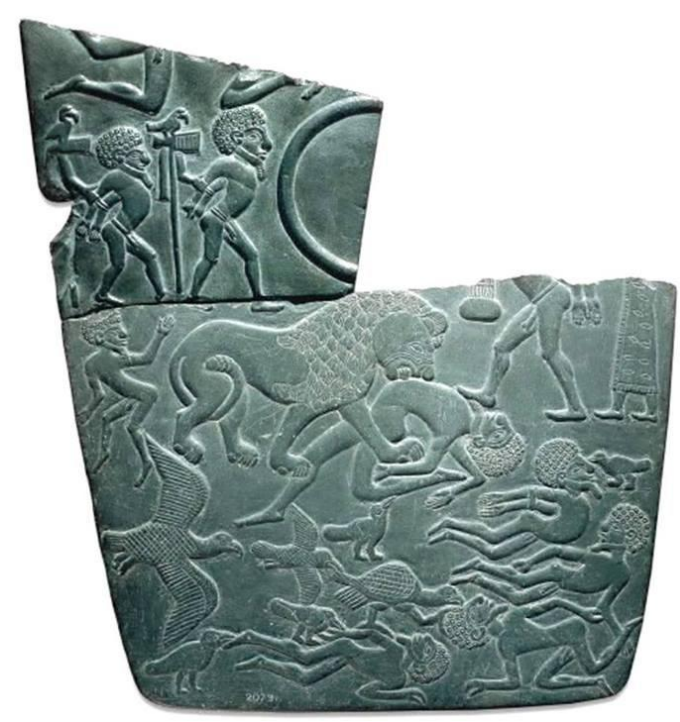

(Fig. 1) Helping the gods in the fighting, standards of Horus with human hands leading the prisoners ("lion and enemies palette" (3150 B.C)

جيفري سبنسر، مصر في فجر التاريخ، ترجمة عكاثة الدالي، القاهرة، 1999، ص 68 شكل 34.

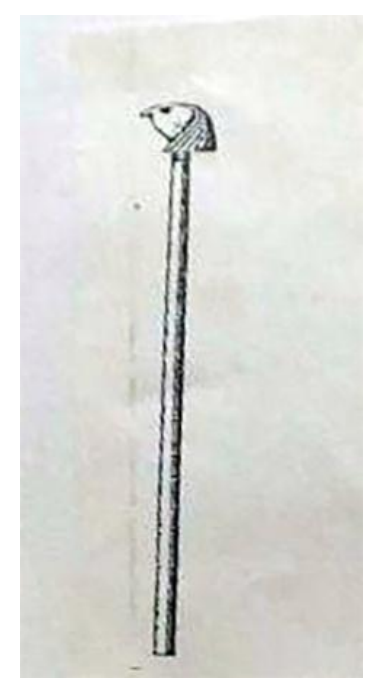

(Fig. 2) Staff of god Horus (from Scenes of the tomb of the King Horwahibre at Dahshur, Now in the Egyptian Museum)

منى عبد العليم عبد اللطيف، العصى المقدة رسالة ماجستير غير منشورة، 2010م، ص 205، شكل 15. 


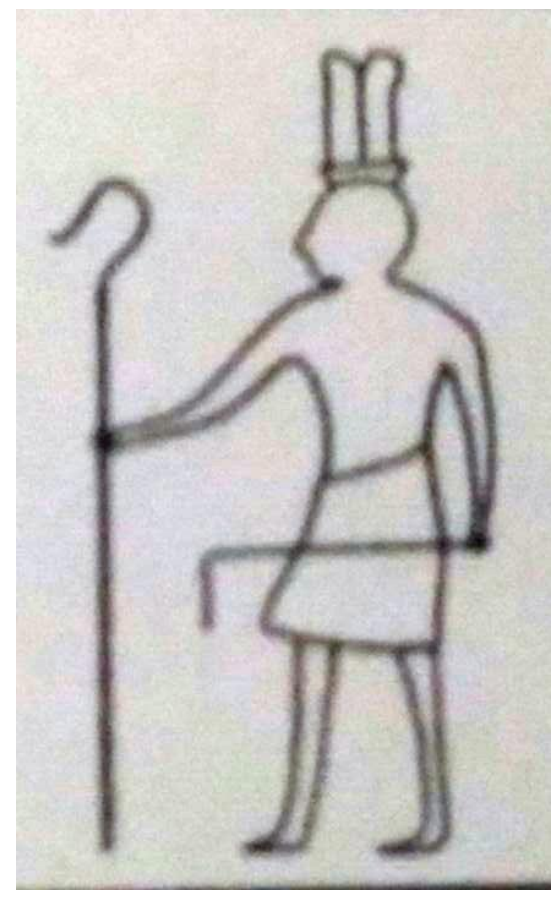

(Fig. 3) The god Andjety in human form holdin his staff with curved end Lurker, M., Götter und Symbole der Alten Ägypter, Germany, 1981, p. 75 taf. 11.

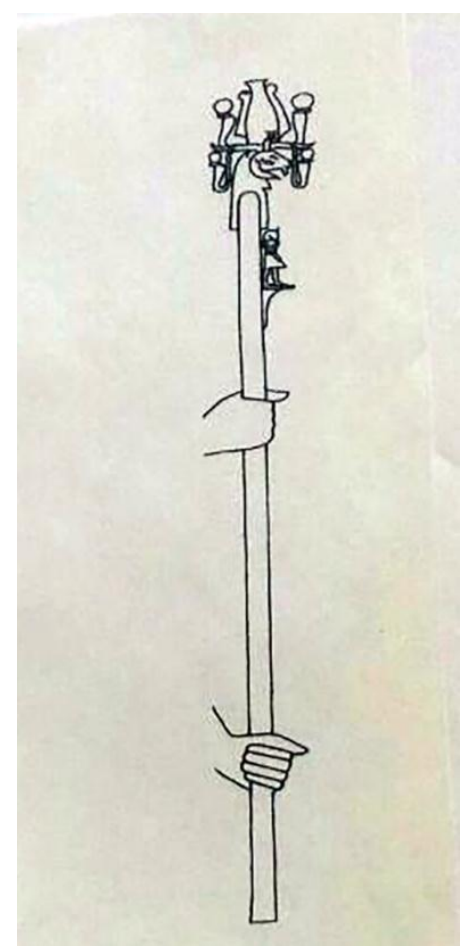

(Fig. 4) The Staff of Amun

$$
\text { منى عبد العليم عبد اللطيف، المرجع السابق، ص 195، شكل } 2 .
$$




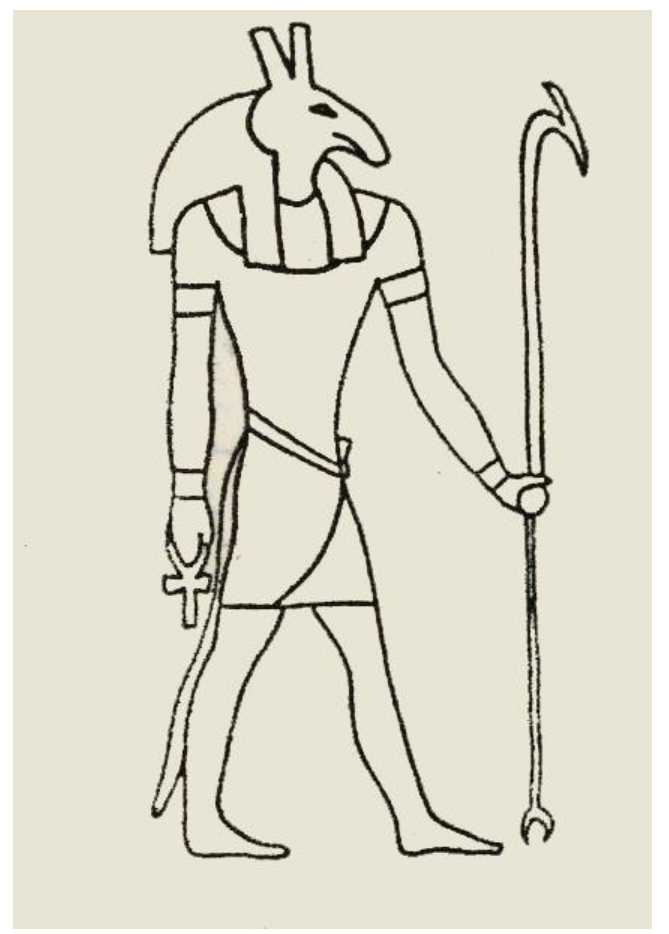

(Fig. 5 a) Seth in an animal-headed human form holding $w 3 s$ scepter

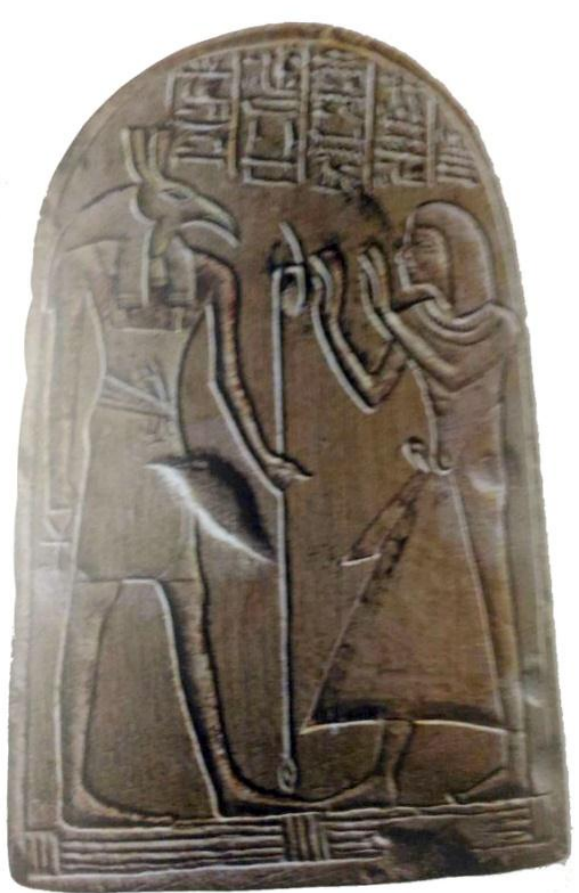

(Fig. 5 b) A craftsman worshiping the god Seth who was depicted in an animalheaded human form, his head seems like the top of $w 3$ s scepter which is held by his hand, $19^{\text {th }}$ Dynasty, limestone, Thebes

The British Museum Book of Ancient Egypt, A.U. in Cairo, 2007, p. 80. 


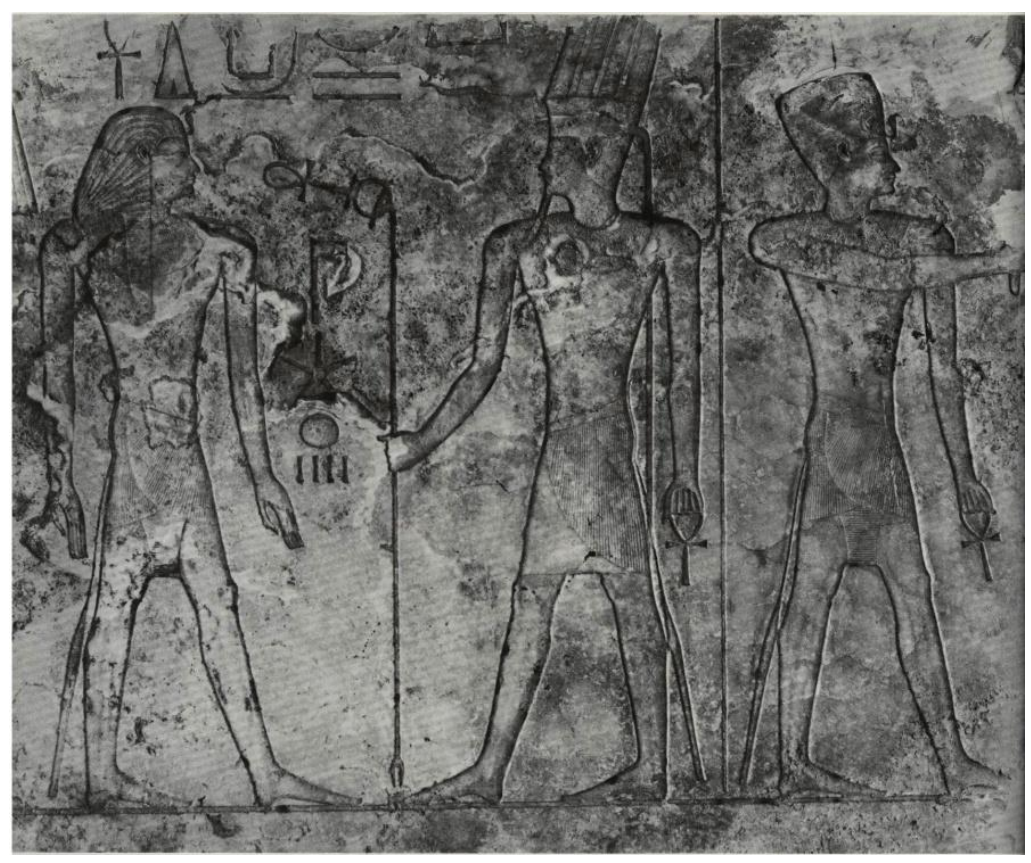

(Fig. 6) The god Amun using the w3s scepter to give life to the king Amenhotep I, from scenes of Karnak Temple Lange, K. and Hirmer, M., Ägypten, München, 1978, p. 124.

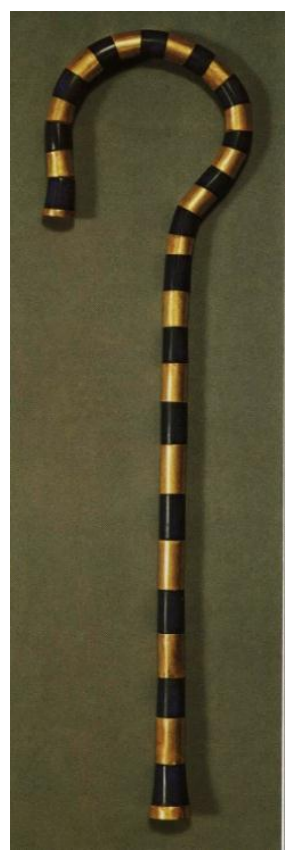

$h k$ 3 scepter (tomb of Tutankhamen, Now in the Egyptian Museum JE. 61759, its height $33.5 \mathrm{~cm}$., bronze and gold)

Tutancchamun Berlin Ägyptisches Museum, 1981. 


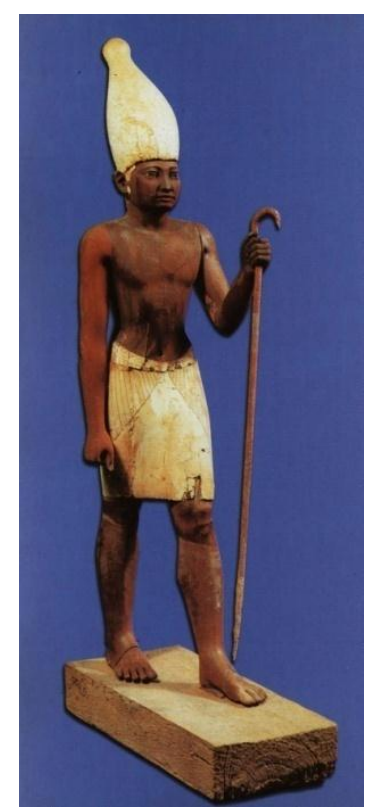

(Fig 8 a) 'wt staff in the king's hand

A small statue of the king Senwosret I was founded in the excavations of

Metropolitan Museum at Lisht in 1915, now in the Egyptian Museum (coloured wood, its height $56 \mathrm{~cm}$., width of base $11 \mathrm{~cm}$. and its length $26 \mathrm{~cm}$.)

$$
\text { محمد صالح- هوريج سوروزيان- كتالوج المتحف المصري، ص } 71 .
$$

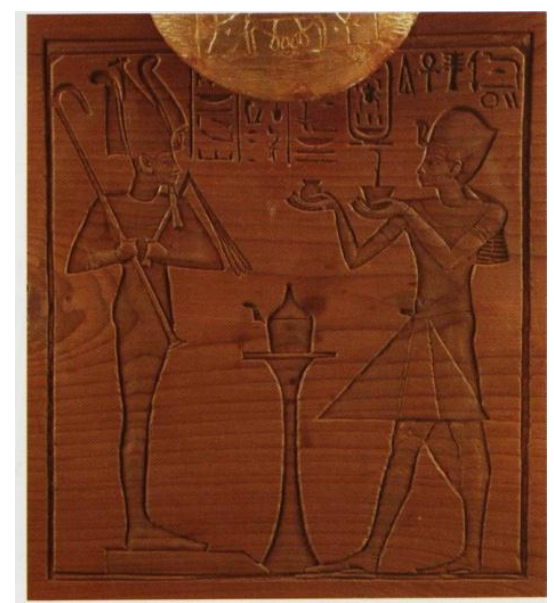

(Fig 8 b) 'wt staff in the god's hand (Egyptian Museum JE. 61445, a scene on a wooden chest from tomb of Tutankhamen)

The offerings are presented to the god Osiris holding ' $w t$ staff in his hand by the king Tutankhamen

Tutancchamun Berlin Ägyptisches Museum, 1980, p. 117, no. 29. 


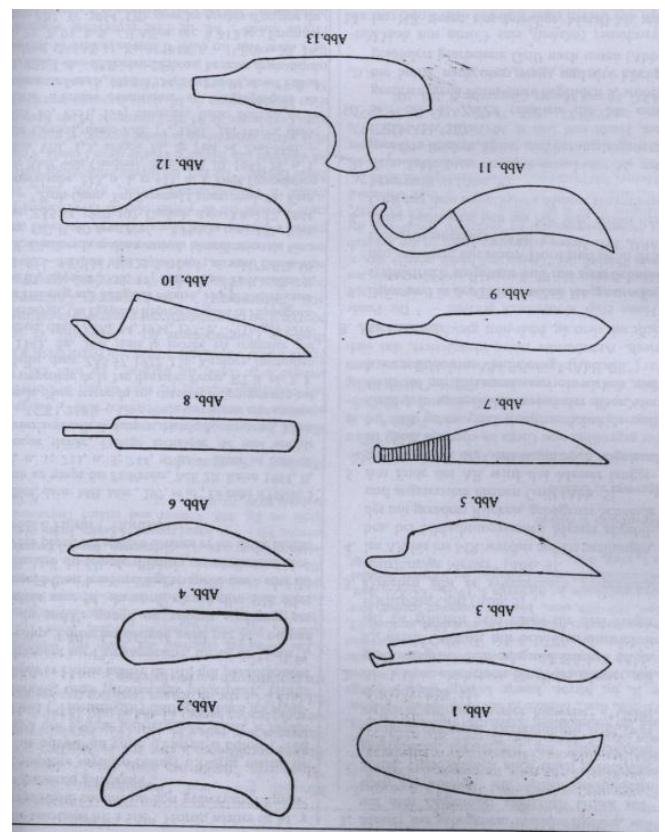

(Fig 9 a) different types of knives

L Ä., IV, p. 111-112.
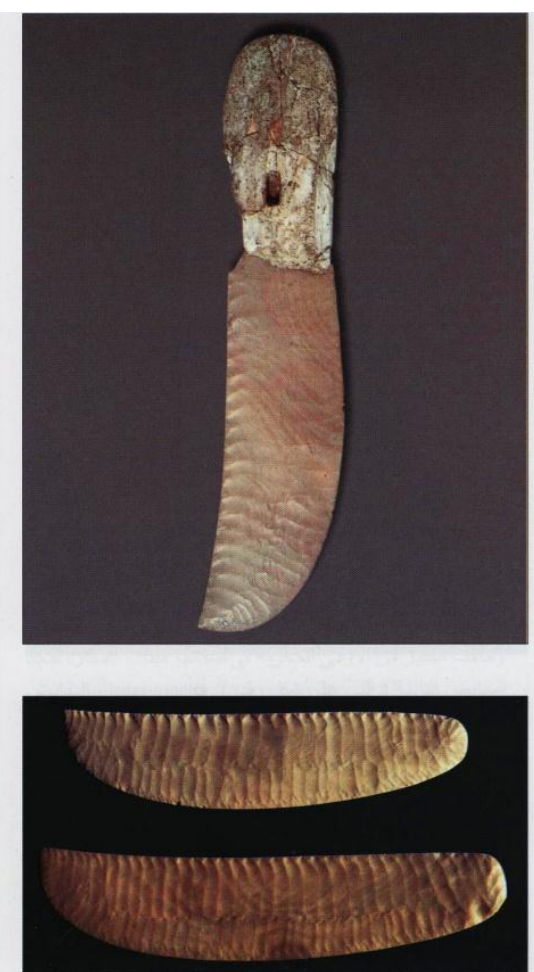

(Fig 9 b) A flint knife with animals' scenes depicting on its ivory handle (from Sheikh Hamada, late predynastic period, its height $26.5 \mathrm{~cm}$.)

جيفري سبنسر، مصر في فجر التاريخ، ترجمة عكاشة الدالي، القاهرة، 1999، ص 52 شكل 26- 


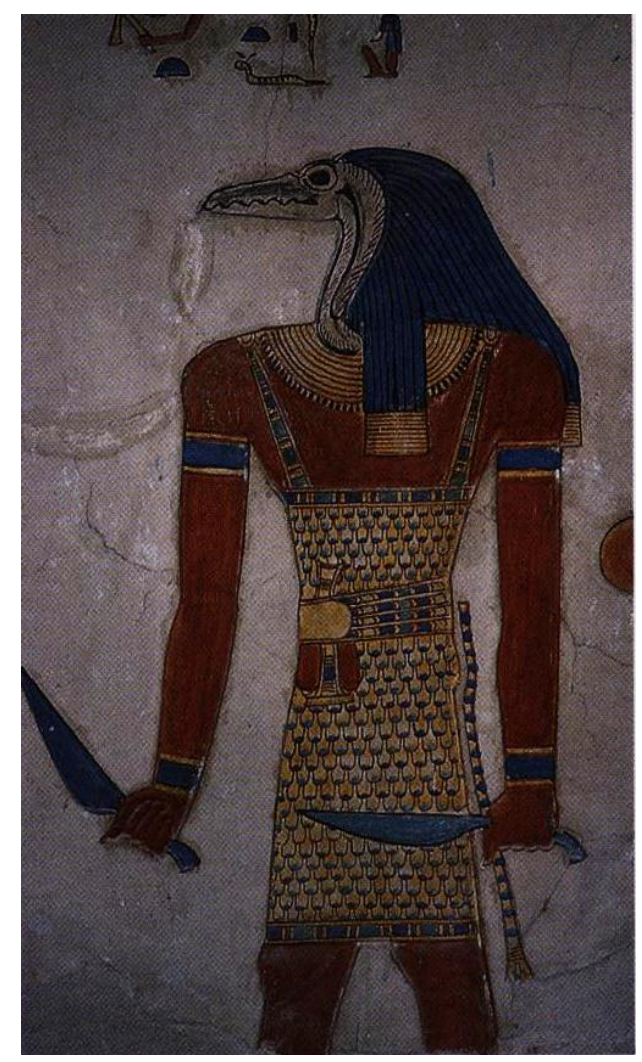

(Fig. 9 c) The religious texts showed that the secondary deities (Genies) were often depicted with weapons such as knives for protection (Scene from the tomb of Amenherkhopshef, Valley of the Kings) Wilkinson, R., The Complete Gods and Goddesses of Ancient Egypt, p. 81.

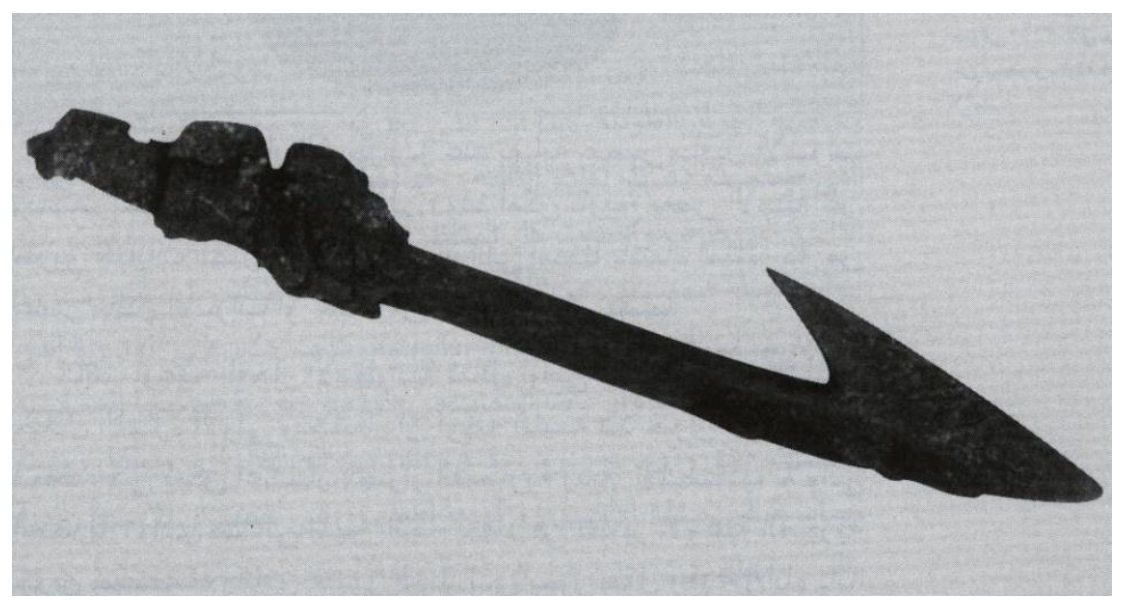

(Fig. 10) blade of harpoon (late predynastic period)

$$
\text { جيفري سبنسر، المرجع السابق، ص } 64 .
$$




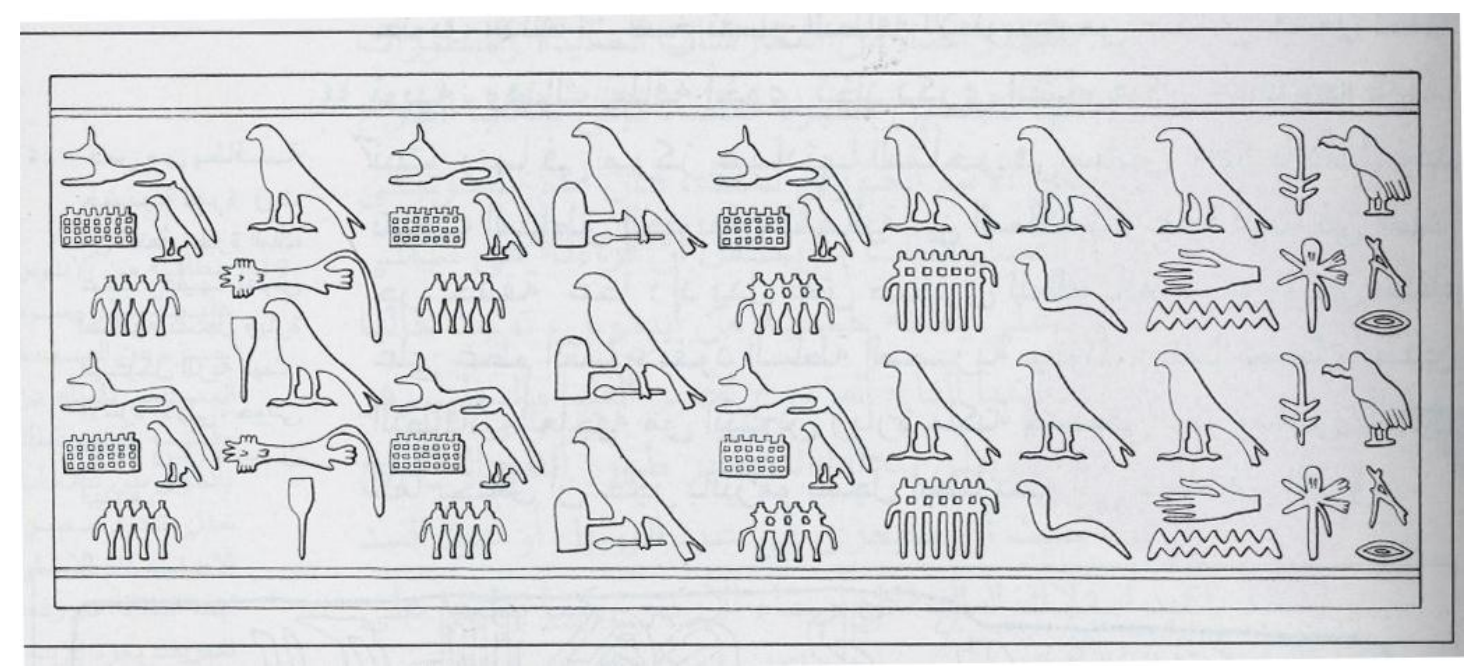

(Fig. 11 a) Horus holding a shield and mace (mud sealing from the royal cemetery at Abydos

$$
\text { جيفري سبنسر، المرجع السابق، ص 81، شكل رقم } 43 .
$$

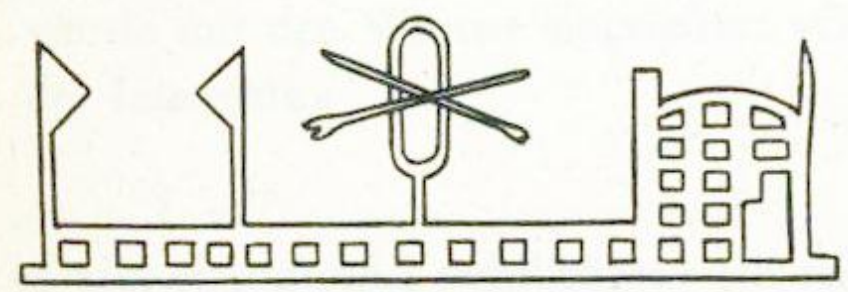

Abb. 36: Alte Darstellung des Heiligtums der Neith: links 2 Fahnenstangen, in der Mitte das Kultsymbol, rechts der Naos.
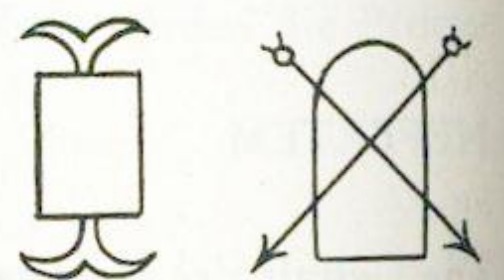

Abb. 37 Symbol Abb. $3^{8}$ der Neith
Gauzeichen von Sais

(Fig $11 \mathrm{~b}$ ) Weapons of the goddess Neith: two crossed arrows with the bow (shield) in the middle of her sanctuary

Lurker, M., Götter und Symbole der Alten Ägypter, Germany, 1981, p. 134, Abb. 36. 


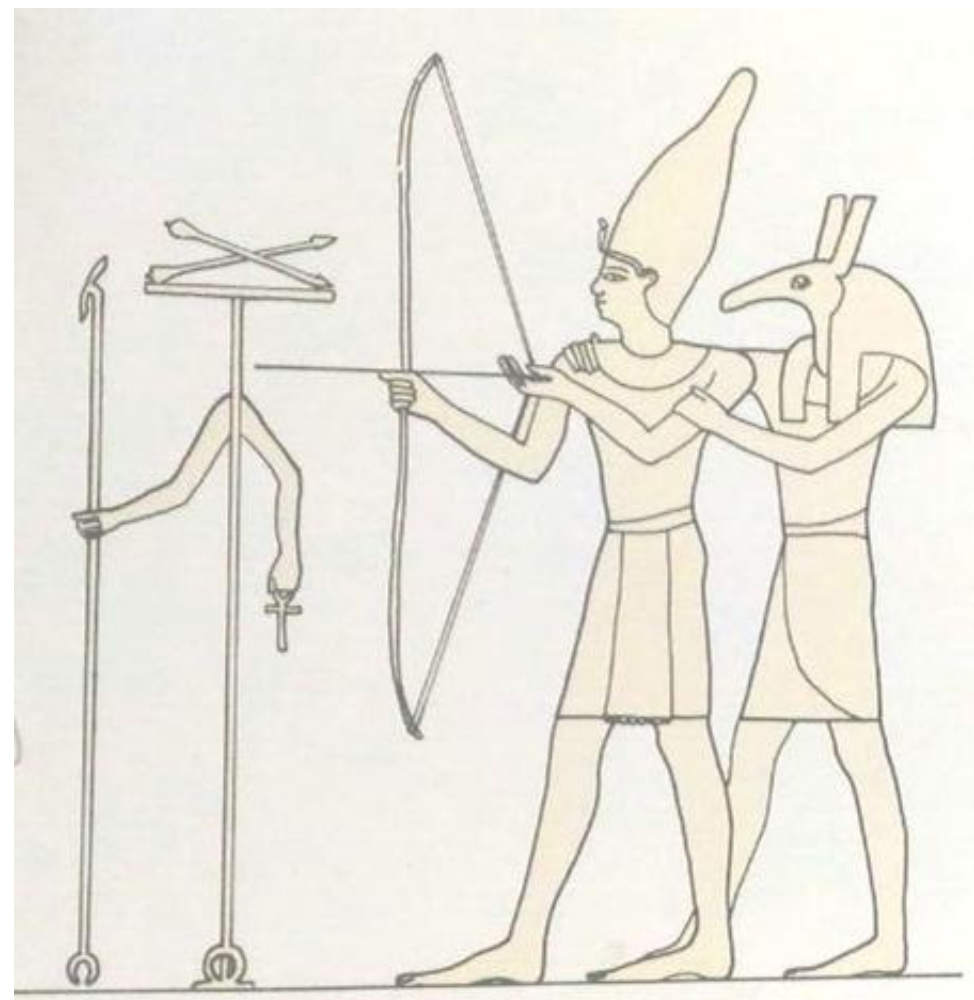

(Fig. $11 \mathrm{c}$ ) The god Seth teaching the archery to the king Tuthmosis III (from the scenes of Karnak temple)

Wilkinson, R., op.cit., p. 199.

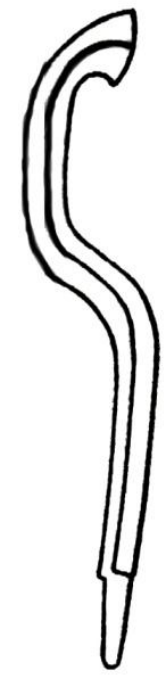

A

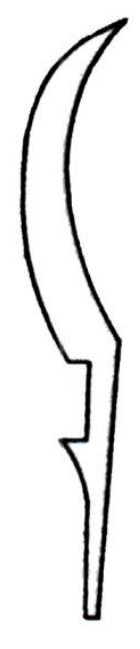

B

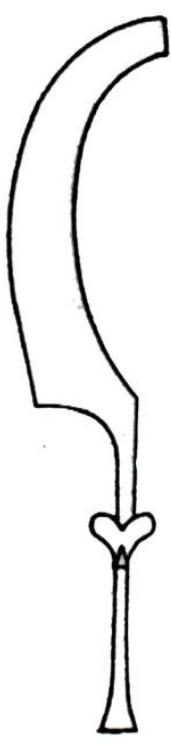

c

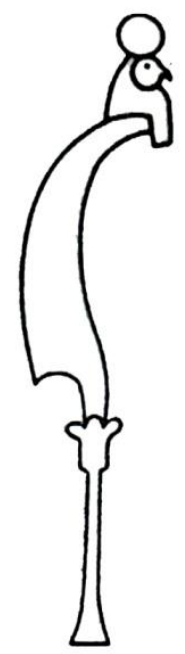

D

(Fig. 12 a) The different types of $h p s ̌ s c i m i t a r$

Schenkel, W., Krummschwert, in: LÄ. III, p. 822. 

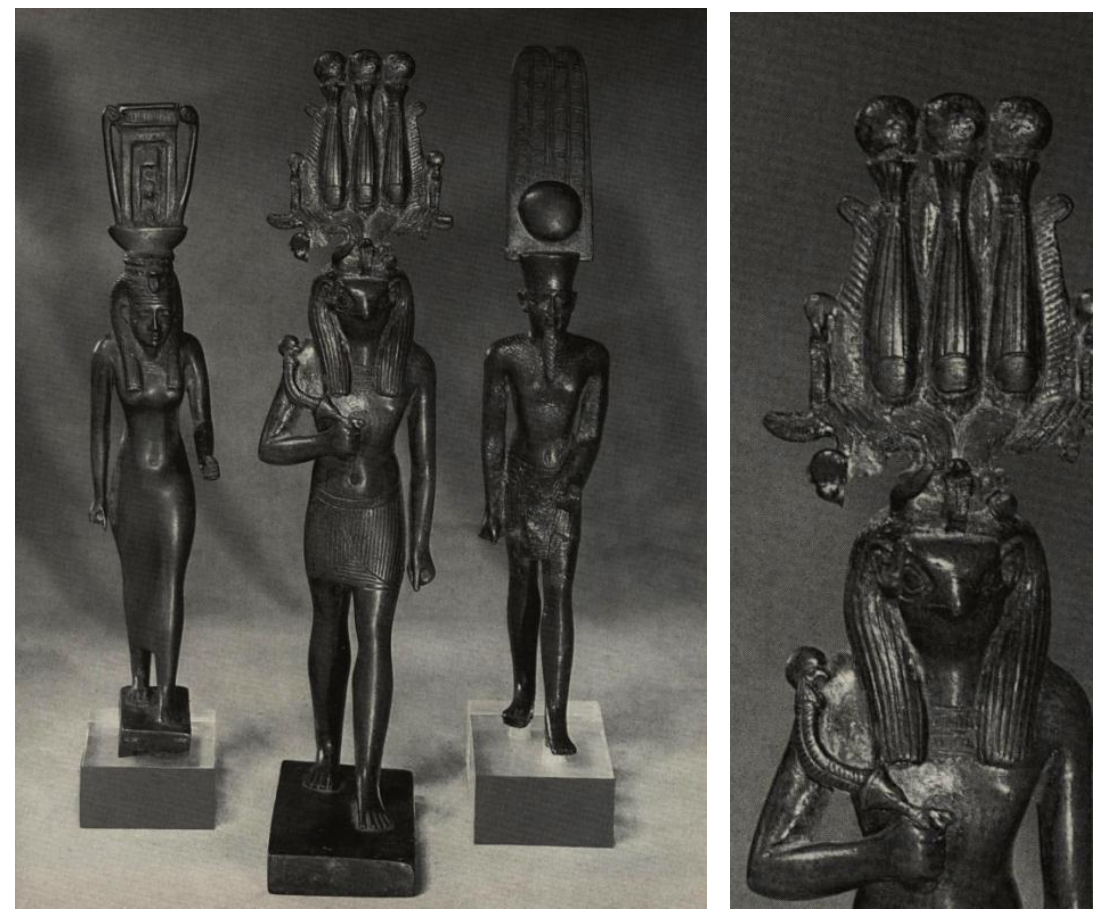

(Fig. 12 b) The god Horus in the middle holding $h p \check{s}$ scimitar (bronze, $26^{\text {th }}$ Dynasty)

Müller, Hans-Wolfgang, Ägyptische Kunst, Germany, 1970, p. 174-175.

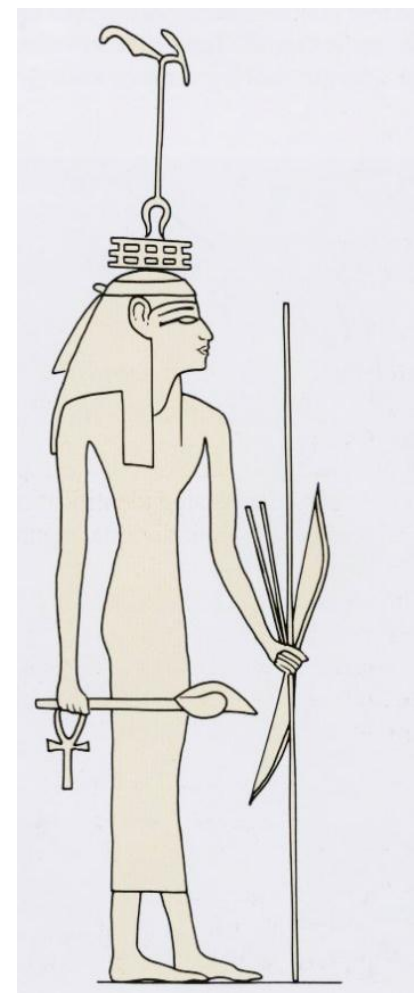

(Fig. 13) The goddess Waset holding the staff, bow, arrows and battleaxe with Ankh sign

Wilkinson, R., op.cit., p. 165. 

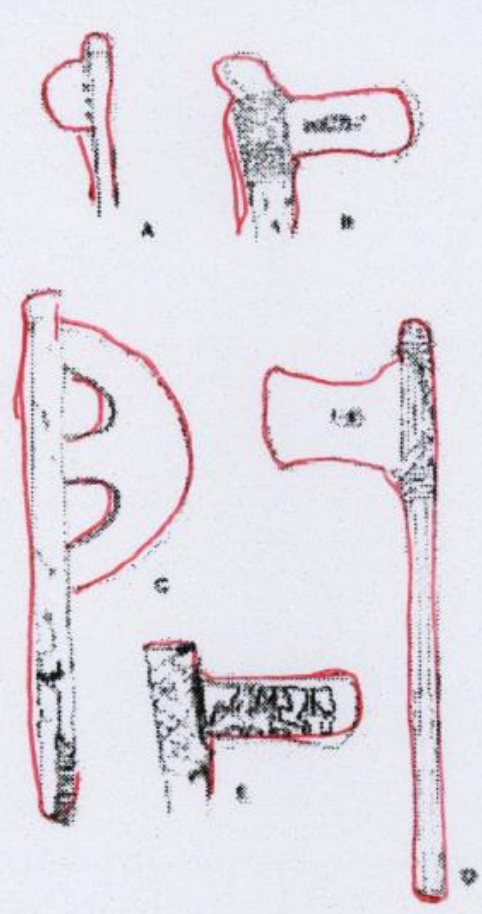

(Fig. 14 a) Copper tools including two blades of battleaxe (from burials dating to the Archaic Period)

مروة محمد كرم، حرس الحدود في مصر القديمة حتى نهاية الدولة الحديثة، رسالة ماجستير غير منشورة، كلية الآثار، جامعة القاهرة، 2011.

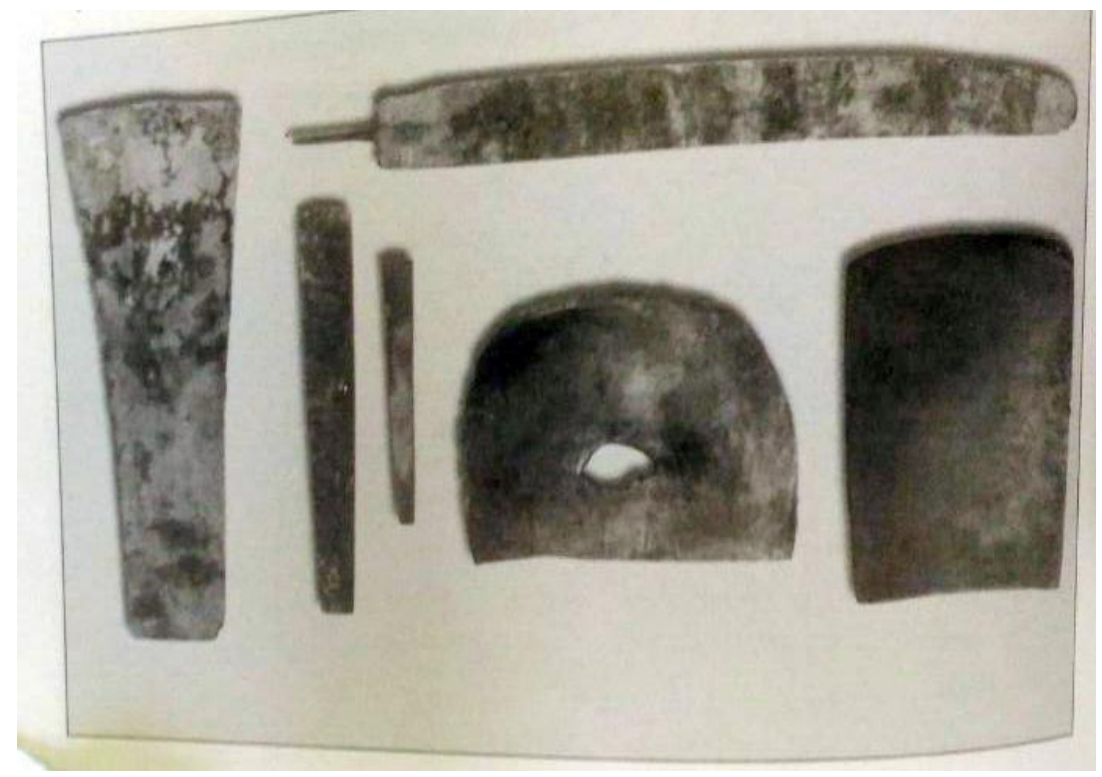

(Fig. 14 b) the different types of battleaxes

$$
\text { جيفري سبنسر، المرجع السابق، ص 108، شكل رقم } 64 .
$$




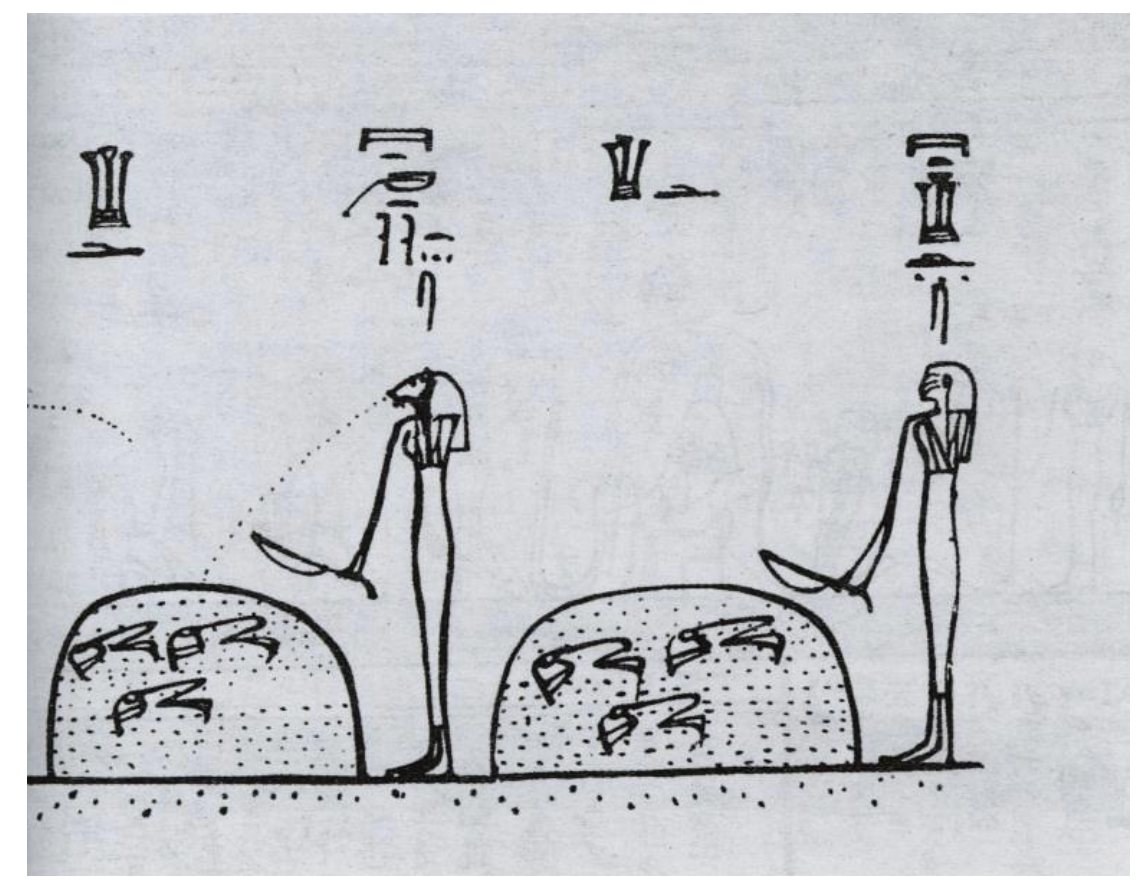

(Fig. 15) Using knives, fire and flames in the Underworld

$11^{\text {th }}$ hour of Amduat (tomb of Tuthmosis III, burial chamber)

إريك هورنونج، وادي الملوك، أفق الأبدية العالم الآخر لاى القدماء المصريين، ترجمة: محمد العزب

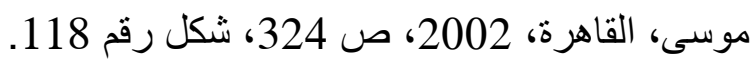

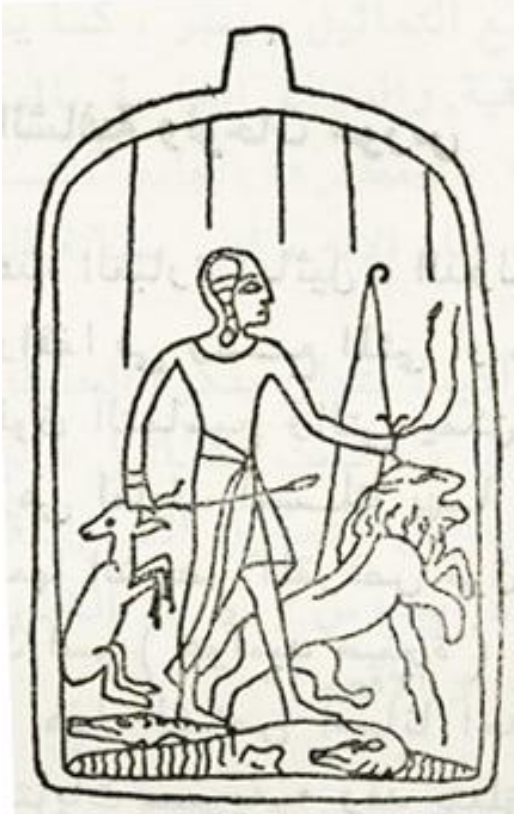

(Fig. 16) The god Shed controlling the harmful evil forces in the magical stelae إيفان كونج، السحر والسحرة عند الفراعنة، ترجمة محمود ماهر، القاهرة، 1999، ص130. 


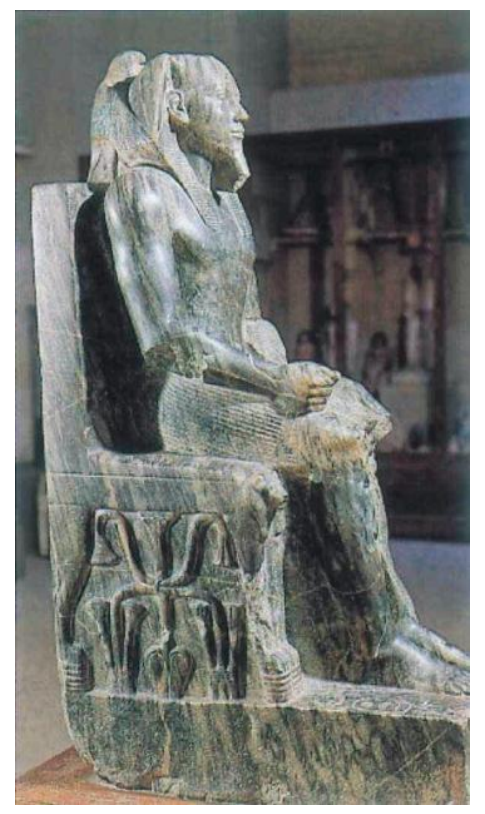

(Fig. 17 a) Using the wings for protection: The falcon Horus stretching his wings for protection behind the king's head

Statue of king Khefern (Egyptian Museum, J.E. 10062, height 168 cm., width $168 \mathrm{~cm}$. length $96 \mathrm{~cm}$.)

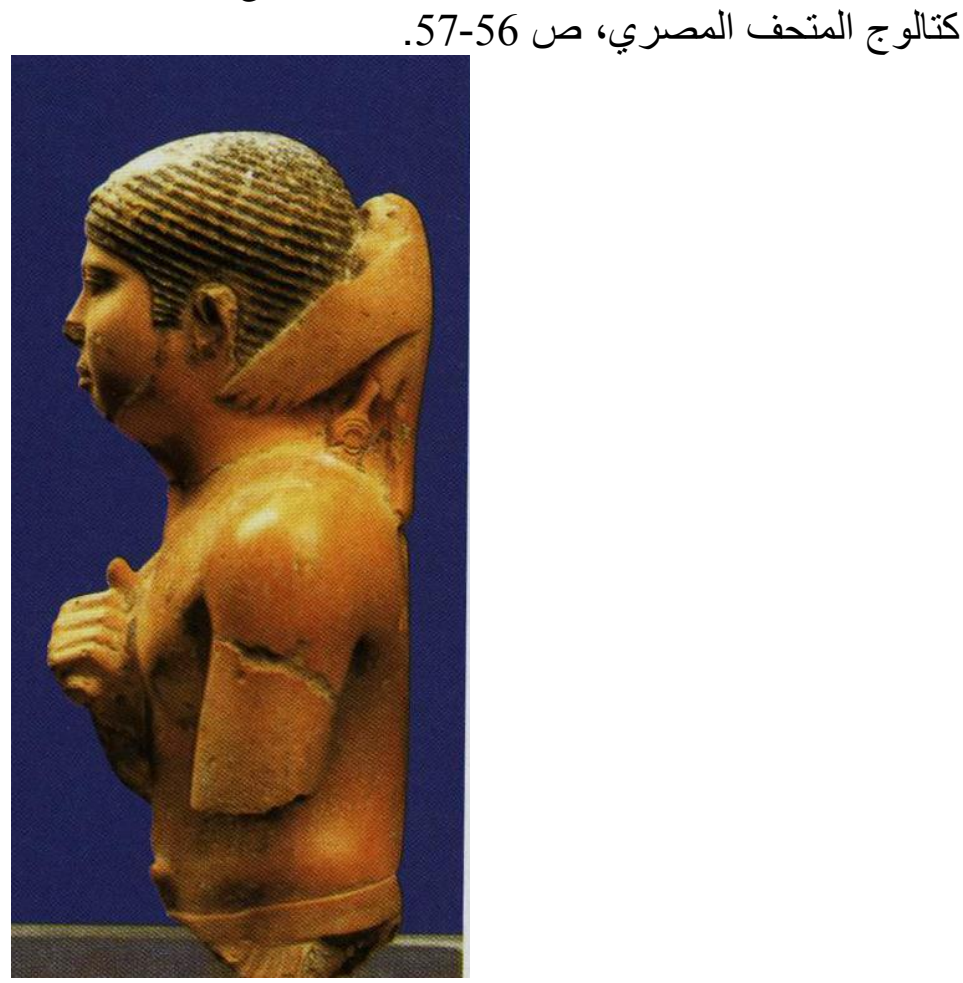

(Fig. $17 \mathrm{~b}$ ) Using the wings for protection

King Neferefre (Old Kingdom $-5^{\text {th }}$ Dynasty- Egyptian Museum JE. 98171, limestone, height $34 \mathrm{~cm}$.)

$$
\text { محمد صالح- هوريج سوروزيان، المرجع السابق، ص 46. }
$$




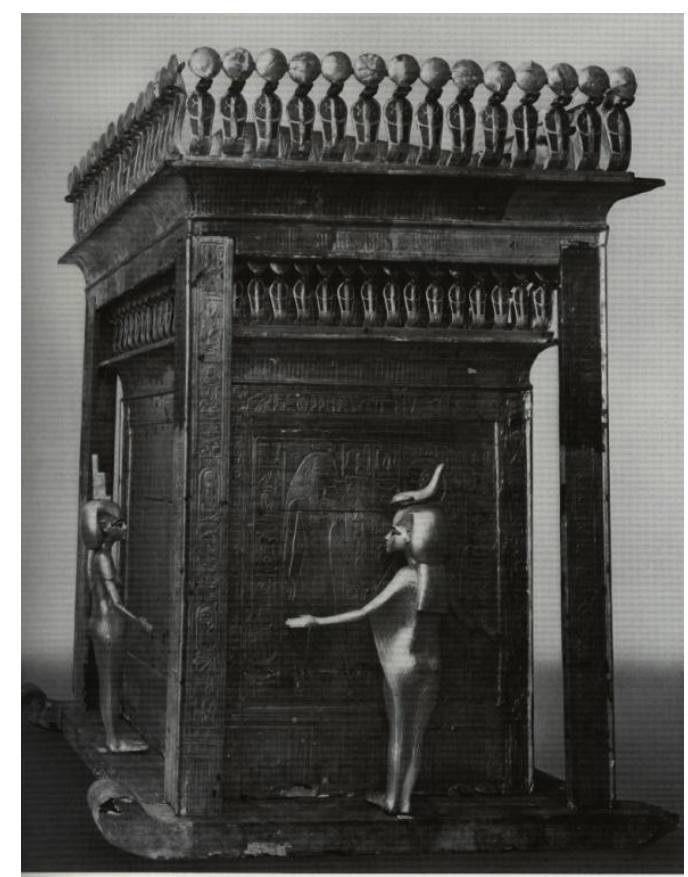

(Fig. 18) Using the wings for protection by the goddesses of protection: Isis, Nyphthys, Neith and Serket محمد صالح - المتحف المصري، ص 121، شكل رقم 92.

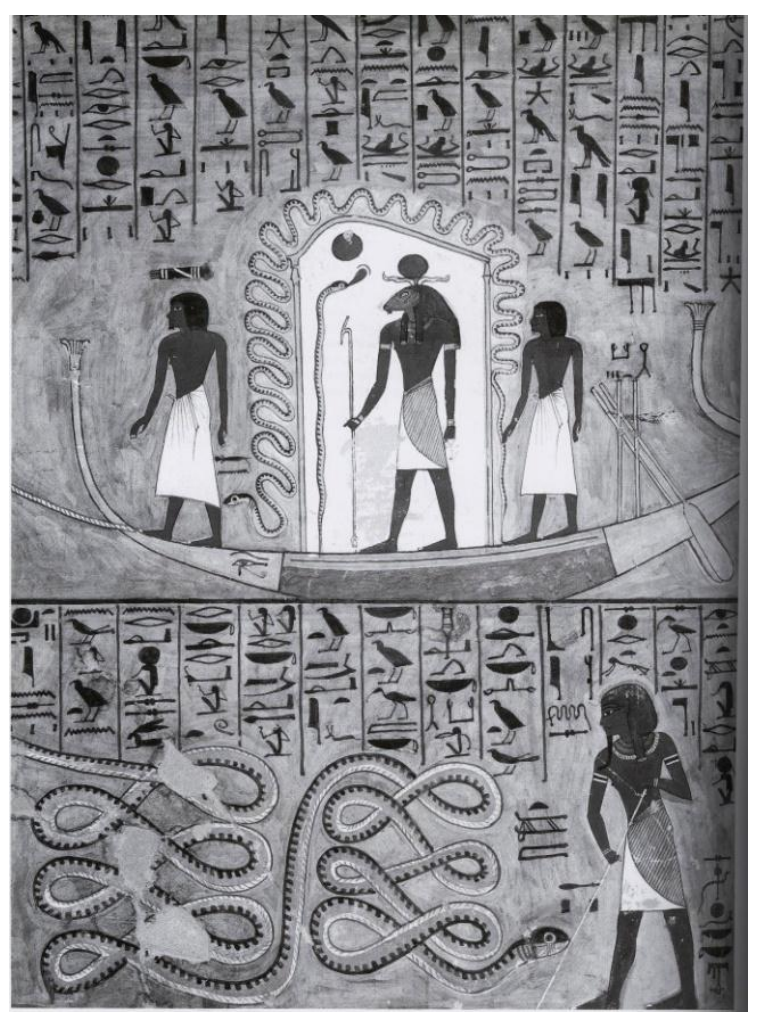

(Fig. 19) Using the wrapping for protection The snake MHn protecting Re in his night journey Wilkinson, R., op.cit., p. 222. 


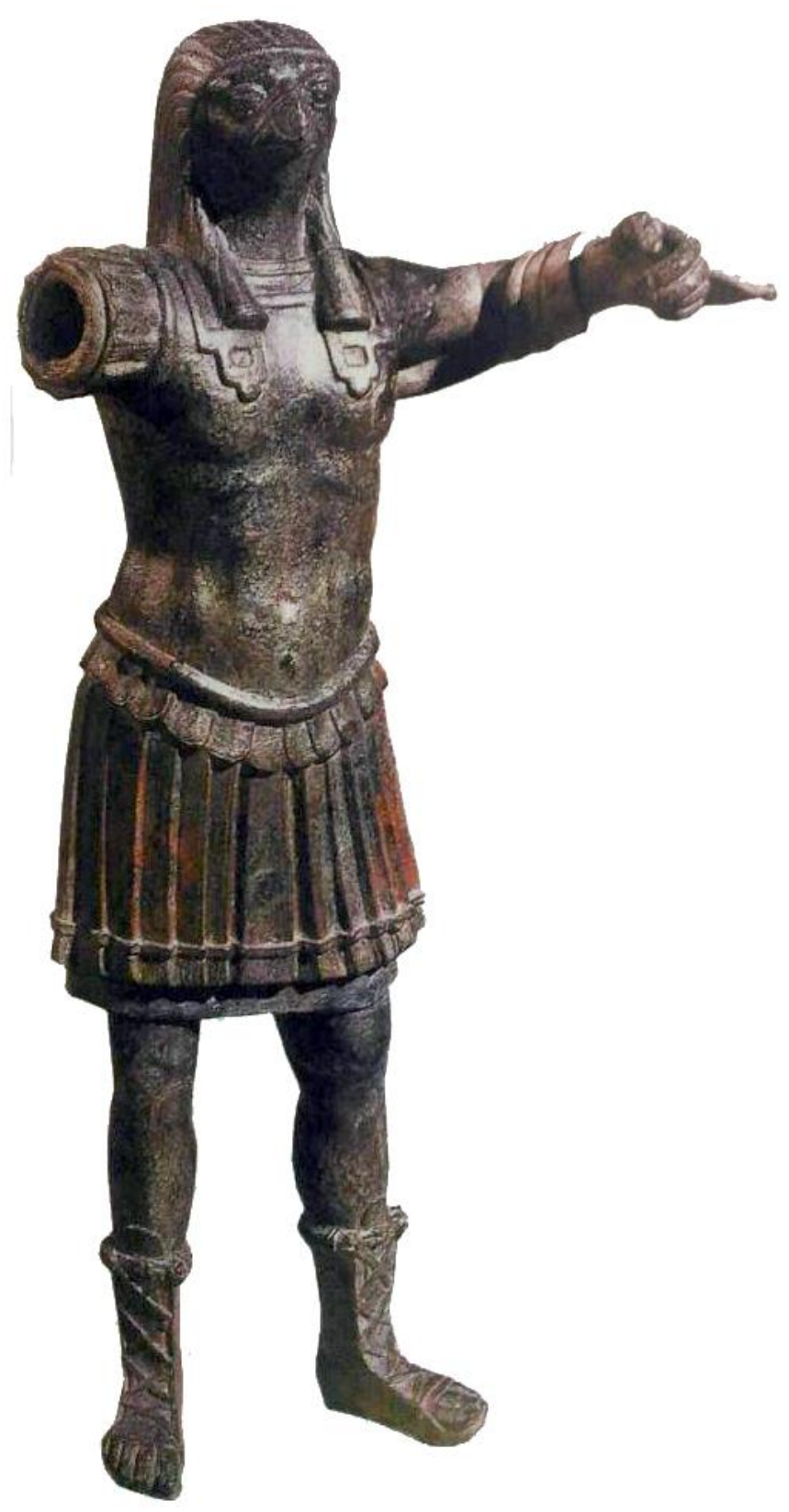

(Fig. 20) The god Horus in a roman warrior with a falcon head (bronze, $1^{\text {st }}$ century A.D, British Museum) Wilkinson, R., op.cit., p. 243.

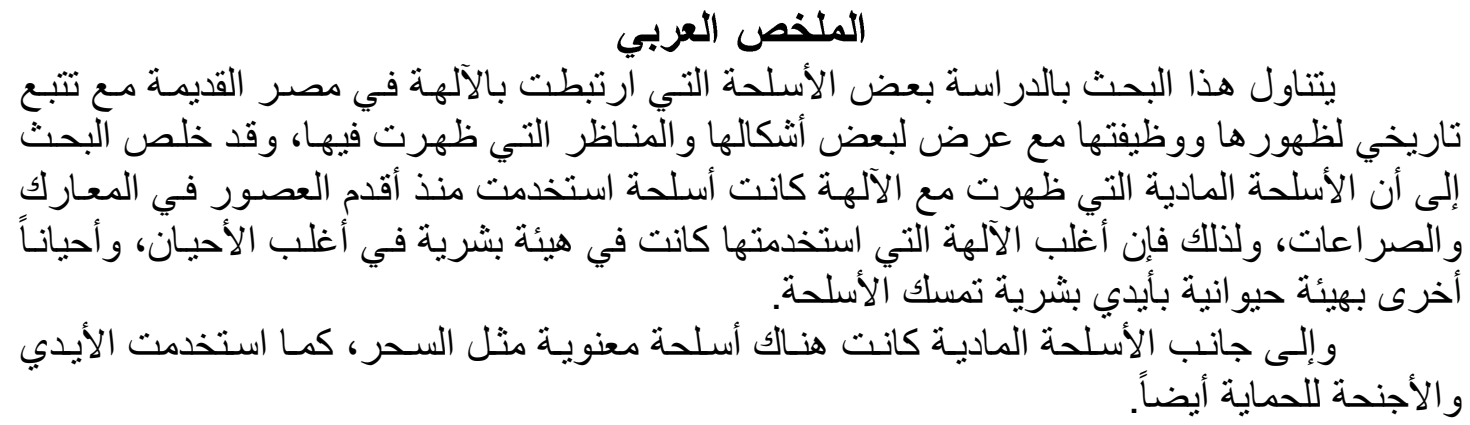

